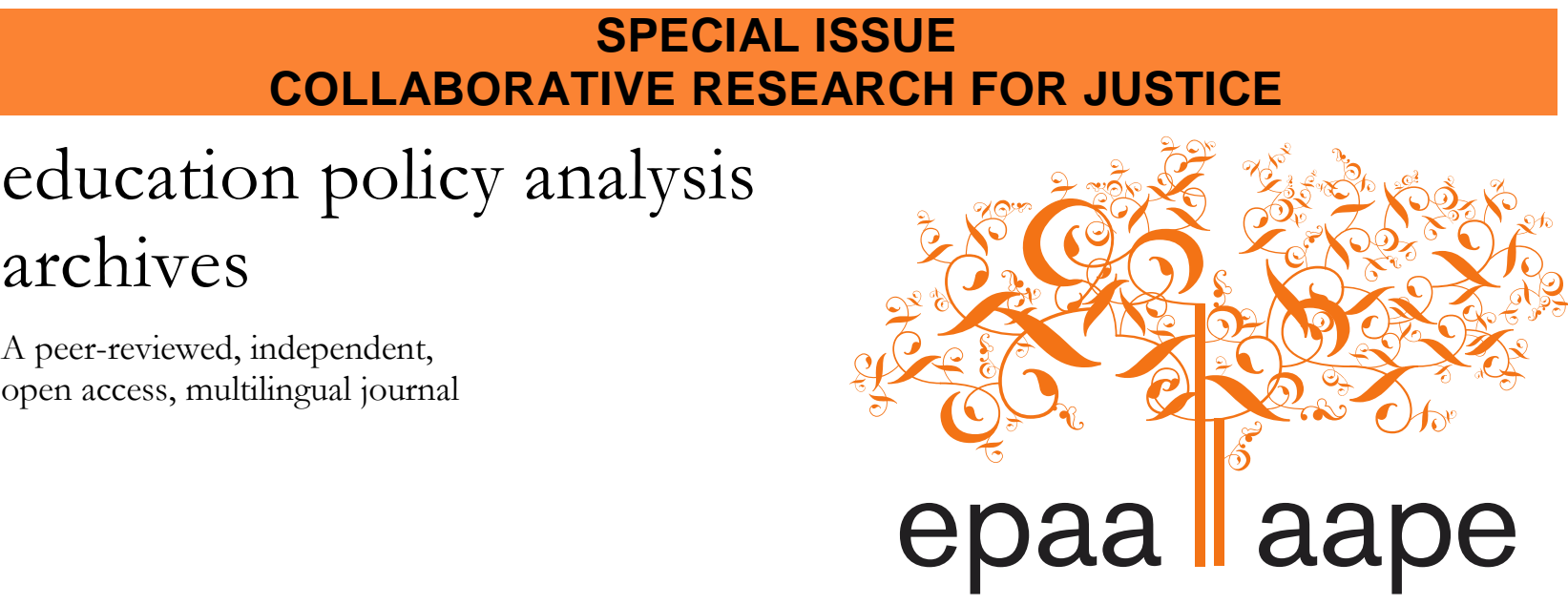

Arizona State University

\author{
Volume 27 Number $56 \quad$ May 20, $2019 \quad$ ISSN 1068-2341
}

\title{
Researching at the Community-University Borderlands: Using Public Science to Study Policing in the South Bronx
}

\author{
Brett G. Stoudt, María Elena Torre, Paul Bartley, Evan Bissell, Fawn Bracy, Hillary \\ Caldwell, Lauren Dewey, Anthony Downs, Cory Greene, Jan Haldipur, Scott Lizama, \\ Prakriti Hassan, Einat Manoff, Nadine Sheppard \& Jacqueline Yates \\ City University of New York \\ United States
}

Citation: Stoudt, B. G., Torre, M. E., Bartley, P., Bissell, E., Bracy, F., Caldwell, H., ... Yates, J. (2019). Researching at the community-university borderlands: Using public science to study policing in the South Bronx. Education Policy Analysis Archives, 27(56).

http://dx.doi.org/10.14507/epaa.27.2623 This article is part of the special issue, Collaborative Research for Justice and Multi-Issue Movement Building, guest edited by Ronald D. Glass \& Mark R. Warren.

Abstract: This article is a case study of the Morris Justice Project (MJP), a participatory action
research (PAR) study in a South Bronx neighborhood of New York City (NYC) designed to
understand residents' experiences with and attitudes towards the New York Police Department
(NYPD). An illustration of public science, the research was conducted in solidarity with an
emerging police reform movement and in response to an ongoing and particularly aggressive set
of policing policies that most heavily impacts poor communities and communities of color. The
case study describes a set of ongoing participatory, research-action, "sidewalk science"
strategies, developed in 42 square blocks of the South Bronx, designed to better understand and
challenge the ongoing structural violence of the carceral state. Collaboratively written with
members of the Morris Justice collective, we tell our story across three sections that outline the
Journal website: http://epaa.asu.edu/ojs/
Facebook: /EPAAA
Twitter: @epaa_aape
Revisions received: $1 / 24 / 2019$
Accepted: $3 / 8 / 2019$ 
genesis of the project, describe our major commitments, and offers PAR and public science as a possible "intervention" in traditional university practice.

Keywords: participatory action research; policing; structural violence; grassroots activism; public science

Investigación en las fronteras de la comunidad-universidad: Uso de la ciencia pública para estudiar la vigilancia policial en el South Bronx

Resumen: Este artículo es un estudio de caso del Proyecto de Morris Justice (MJP), un estudio de investigación de acción participativa (PAR) en un vecindario del South Bronx de la Ciudad de Nueva York (NYC) diseñado para comprender las experiencias y las actitudes de los residentes hacia Departamento de Policía de Nueva York (NYPD). Una ilustración de la ciencia pública, la investigación se llevó a cabo en solidaridad con un movimiento de reforma policial emergente y en respuesta a un conjunto de políticas policiales en curso y particularmente agresivo que afecta más a las comunidades pobres y las comunidades de color. El estudio de caso describe un conjunto de estrategias participativas en curso, de investigación-acción, "ciencia de acera", desarrolladas en 42 bloques cuadrados del South Bronx, diseñadas para comprender mejor y desafiar la violencia estructural en curso del estado carceral. Escrito en colaboración con miembros del colectivo Morris Justice, contamos nuestra historia en tres secciones que resumen la génesis del proyecto, describimos nuestros principales compromisos y ofrecemos PAR y ciencia pública como una posible "intervención” en la práctica universitaria tradicional. Palabras-clave: investigación acción participativa; violencia policial; activismo; ciencia pública

\section{Pesquisa nas fronteiras da comunidade-universidade: Uso da ciência pública para estudar vigilância policial no South Bronx}

Resumo: Este artigo é um estudo de caso do Morris Justice Project (MJP), um estudo de pesquisa de ação participativa (PAR) em um bairro no South Bronx, em Nova York, projetado para entender as experiências e atitudes dos moradores em relação ao Departamento de Polícia de Nova York (NYPD). Uma ilustração da ciência pública, a pesquisa foi conduzida em solidariedade com um movimento emergente de reforma da polícia e em resposta a um conjunto de políticas policiais em andamento e particularmente agressivas que mais afetam comunidades pobres e comunidades de cor. O estudo de caso descreve um conjunto de estratégias participativas de pesquisa-ação, "ciência da calçada", desenvolvidas em 42 quarteirões do South Bronx, destinadas a melhor compreender e desafiar a violência estrutural em curso no Estado carcerário. Escrito em colaboração com membros do coletivo Morris Justice, contamos nossa história em três seções que resumem a gênese do projeto, descrevem nossos principais compromissos e oferecem a PAR e a ciência pública como uma possível "intervenção" na prática universitária tradicional. Palavras-chave: pesquisa-ação participativa; violência policial; ativismo; ciência pública 


\section{Researching at the Community-University Borderlands}

I am a wife and a mother of two sons. One day my oldest son came home and said the police broke his phone - he told me these things happen all the time. By 2010 it had only gotten worse. Me and two other mothers (Fawn and Nadine) living in our complex were fed up with how the police were harassing our sons. Fawn even had to relocate to New Jersey after 16 years to protect her son. Don't get me wrong, we're not against policing, we're against the police abusing and disrespecting our sons. They shouldn't be targeted because of where they live and the color of their skin. We wanted to show our children things COULD change. We CAN make a difference. That's when we met Brett and Maria and began the Morris Justice Project.

Jackie, Morris Justice researcher, 38-year resident of the

South Bronx, delivering an address to an audience of dignitaries at a White House Forum on Citizen Science in the fall of 2015 on behalf of (and co-written by) the Morris Justice Project research collective.

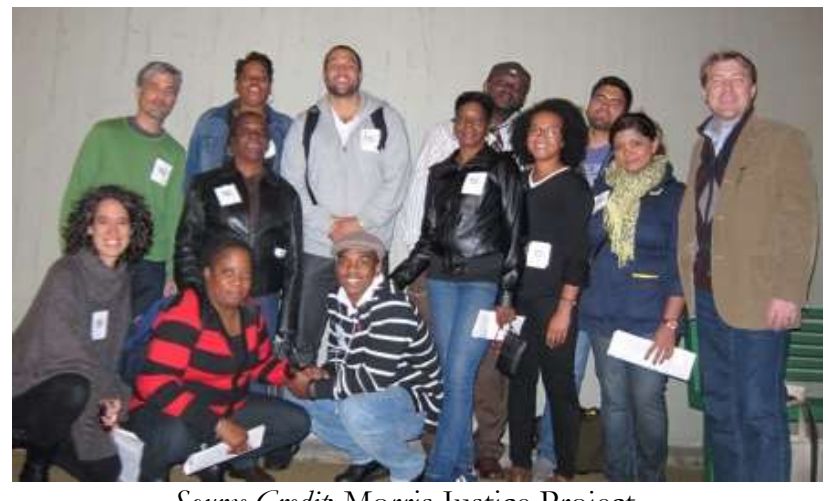

Source Credit: Morris Justice Project

As Jackie describes, we are a research collaborative studying the consequences of aggressive policing policies in New York City (NYC), specifically in 42 blocks of a South Bronx neighborhood (see morrisjustice.org; Stoudt \& Torre, 2014; Stoudt et al., 2015). Most members of our collective live in the South Bronx where our research takes place, while a few of us live in other parts of the City. Some of us are founding members of the project and others joined at, or for, various stages along the way. We are a radical collective of many different lived experiences and so, in the following pages, we will discuss in detail with you our research by weaving our multiple voices (quotes) into a collective narrative. To do this, we wrote the piece together through an iterative process that began with assembling a long list of questions to help us focus our reflection on the project. We interviewed each other and used the themes emerging from our transcribed conversations to draft a paper that was then discussed and revised by the group until we felt it represented a version (as there are multiple) of our collective story. The many direct quotes used to tell our story should be understood as providing an intimate peak into our process from the various standpoints of those who lived it. This "finished" version will highlight the conditions, ethics, assumptions, decisions, challenges, and possibilities that emerged in and from participatory research at the community-university borderlands.

Why policing? We came together to study policing for a variety of reasons. We are young people, mothers, fathers, and grandparents who thought "the stop-and-frisk thing was really getting out of hand" (Paul). We got tired of "the police harassing our sons and the other kids living in the 
neighborhood" (Fawn) and "wanted them to know it doesn't have to be like this" (Jackie). So we joined the project "to see what we could do about it" (Nadine). A few of us joined because of our personal experiences in prison and realizing "there's a lot of people in there who don't deserve to be there" (Anthony) or growing up and getting stopped by police "everyday, all-day - hallway, courtyard, corner - so many times I can't even count" (Cory). Others had less personal experience and "became convinced about the need to do something about the police by doing the work involved in the project" (Prakriti). Some were students who "have always been involved with criminal justice issues" (Jan) or saw an opportunity to use "research for change" (Lauren) or wanted to "learn how art could be a part of participatory research to advance social justice" (Evan). Other students "witnessed some stops that have been really upsetting" (Hillary), "began learning about police reform and had design skills to offer" (Scott), or drew connections with involvement in "justice work with Internally Displaced Palestinians" (Einat). Two in the group are professors who researched with "people who were incarcerated or formally incarcerated" (María) and learned from former projects that "something was beginning to boil in NYC around policing" (Brett).

Why research? The authors of this paper represent most of the people who significantly contributed to the Morris Justice Project over the years. There are some that went off to college, moved out of state, retired, or felt too vulnerable/targeted to continue with the project. All of us, however, across our different backgrounds and experiences had common burning questions about "what the hell is going on with the NYPD" (Anthony). We were angry, frustrated, and we wanted to do something about it. We understood our research to have multiple purposes - to learn, to educate, to advocate, to connect with activists, lawyers and policymakers, to bridge awareness of experiences/attitudes among neighbors, and to help facilitate a conversation about the role of police in the community. We thought it important to use multiple quantitative and qualitative methods (surveys, focus groups, interviews, maps, public data as well as embodied and creative methodologies such as art, photography, and play) in order to communicate with the various community members, stakeholders, and decision makers with whom we interacted over the last halfdecade. We have been together for over five years in terribly precarious times and most everything, from our first meeting to collecting and analyzing data to writing this article, was/is done collaboratively.

How should you understand our collective? As individuals, we are of course more than our project and not easily stereotyped. Many of us play lotto and like a drink or two (one of our most frequented meeting spaces is the local tavern). Some of us are religious and others atheist, some were involved with the Black Panthers and others Occupy Wall Street. A few of us like to write, some paint, at least one collects rocks, and several enjoy watching basketball. We each came to the group with different and sometimes shared social networks. Several of us already knew each other and held mutual acquaintances while others of us became friends through the project. There are endless ways we could divide or organize ourselves as a collective. Our relationships to each other and to our research are often described as "community members" and "university members," collapsing and making central our neighborhood and work positionalities. While these subjectivities are certainly important in how we are situated to each other and our research, we are also - as individuals and a collective - located in ways too numerous and overlapping than such an over simplified (and assumptive) divide. Whatever our professional and personal backgrounds, through this project we all took responsibility to move forward our research, analysis, activism, organizing, writing, public speaking, and knowledge production. For purposes of this academic journal article, the community/university distinction is certainly present and meaningful for our group, but it also 
must be understood that for us, in practice and over the course of many years together, these distinctions are more complicated and varied (as they should be). ${ }^{1}$

How should you understand our work? This case study is about participatory action research (PAR) as a strategy to produce grassroots scholarship that is working against the reproduction of the historical legacy of exploitation and misrepresentation of communities of color by universities and university research. More specifically, it is about how the Morris Justice Project braided research and activism in order to contribute to the NYC police reform movement. Through a detailed discussion of our praxis (Freire, 2000), we will show how PAR can be a form of public science, illustrating a set of locally focused, ongoing research-action strategies that were designed to challenge the ongoing structural violence of the carceral state. This is a long article. We had a lot to say! If nothing else, we hope you take away four main points:

1. We pursued PAR as a strategy to address the structural harms of policing while not reproducing the potential structural harms of traditional social science conducted in/on communities of color.

2. Our approach can be defined as a strong commitment to diverse community relationships to foster productive research spaces for critical dialogue, ongoing inquiry, and activism.

3. Our project not only served as a strategy to intervene/interrupt aggressive policing policies, it also served as an intervention within the university, helping challenge and expand the structural limits of elitist university research cultures.

4. Ultimately, this is an article about public science, a praxis of research that simultaneously commits to social justice and social science; one that speaks to pressing theoretical and practical concerns, refusing the distinctions between theoretical and applied, or science and advocacy; one that practices radical academic inclusion by extending notions of expertise and making central the knowledge of those traditionally excluded and harmed by the university (see Clawson, 2007; Fine \& Barreras, 2001; Stein \& Daniels, 2017).

In this piece we offer the Morris Justice Project as one illustration of public science.

\section{The Violence We Live, The Violence We Represent: The Genesis of the Morris Justice Project}

Community-university partnerships are delicate relationships that deserve attention. For the Morris Justice Project, when Brett, María and others from the university joined with Jackie, Fawn, Nadine and others from the South Bronx, two long histories of structural violence were brought together. One was the history of state violence through racist policing and incarceration policies and practices (Alexander, 2012). It was this violence that ignited our project and motivated our desire for transformation. The other violence was the history of university exploitation of communities outside it, too often racist and colonial in nature (Smith, 1999). We start with the NYC policing context as structurally violent (Farmer, 1996), move to some of the university restraints as part of that violence, and conclude with a call for public science as practiced through PAR.

\footnotetext{
${ }^{1}$ Moving forward, we use "community" as shorthand for the South Bronx area our study focused on and where most from the Morris Justice Project live. We use "university" to represent the City University of New York, where some from the Morris Justice Project work or are getting educated. We acknowledge this is a complicated and in many ways false dichotomy. "Community" is not monolithic, "community" exists at the university as well, and members of our collective have or are currently living in both spaces.
} 


\section{The Structural Violence of Policing}

For over 20 years NYC has been policed under the framework of "Broken Windows." Also known as order-maintenance policing (and associated with zero-tolerance policing), the basic philosophy of Broken Windows is that removing signs of "disorder" from communities maintains or produces an environment where order (and those who are "ordered") prevails (Kelling \& Wilson, 1982). In the context of NYC, drinking in public, selling loose cigarettes, riding a bike on the sidewalk, showing small amounts of marijuana in public view, or being in the park after-hours are all examples of disorder to the NYPD (Harcourt, 2001). Informed by the theoretical framing of Broken Windows, police officers in so-called "disordered," higher crime NYC neighborhoods rely on the use of heavy surveillance tactics like "stop-and-frisks", asking for IDs, telling people to "move" (Camp \& Heatherton, 2016) as well as handing out record numbers of violations (citations, summons, and tickets) and making misdemeanor arrests (Chauhan et al., 2014; Chauhan et al, 2015). These and other forms of constant surveillance are believed to prevent incidents of what the police consider are more serious crimes (Rios, 2011). Broken Windows in NYC also involves practices such as "vertical policing" in which police sweep lobbies, hallways, courtyards, and rooftops of public and private housing as well as increased police presence in schools through NYPD School Safety Agents and officers, metal detectors, and surveillance cameras (Stoudt, Fine \& Fox, 2011).

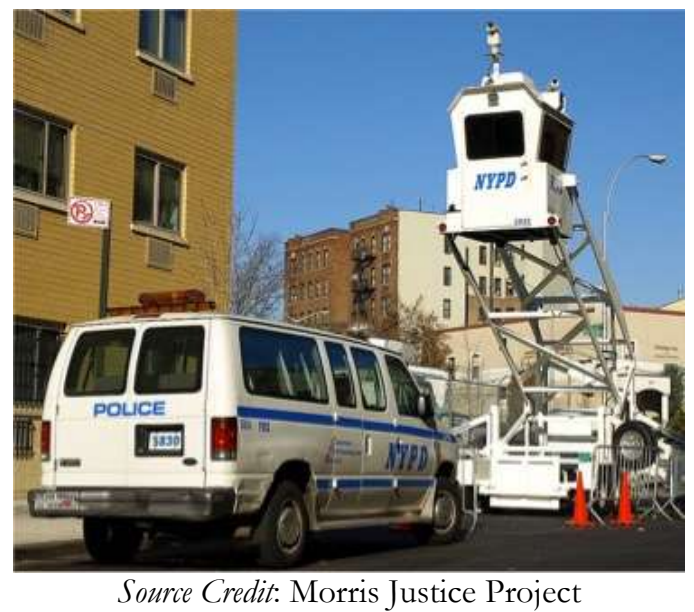

The logic of Broken Windows policing produces/justifies a way of "seeing disorder" that is steeped in racist assumptions about the origins of criminality and the nature of the criminal as "hardened," as unredeemable, as needing to be punished and contained (e.g. the "super predator") (Camp \& Heatherton, 2016). Indeed, Broken Windows represents the latest "commonsense" orientation to public safety in an old and ongoing story in which poor and marginalized, usually black and brown bodies, are controlled and punished by the state through the criminal justice system in ways that protect and advance the political and capital interests of the privileged class (Gilmore, 2007; Wacquant, 2009; Websdale, 2001). It is an enactment of the well-documented, structurally racist violence written into the fabric of our laws, institutional logics, political interests, social norms and everyday relations that can be traced in one continuous line historically from chattel slavery, the redemption period, Jim Crow, until now - what has come to be known as the "New Jim Crow" (Alexander, 2012; Muhammad, 2011; Platt et al., 1982). Researchers, lawyers, and other police departments have convincingly demonstrated the flaws in the Broken Windows logic and found its practices to be largely ineffective and harmful (Camp \& Heatherton, 2016; Harcourt, 2001). Despite this, police, politicians, and conservative think tanks have widely credited it with the significant drop 
in recorded NYC crime (Kelling \& Bratton, 2015). As a result, the approach has been extensively exported nationally and internationally (Camp \& Heatherton, 2016). What does Broken Windows look like by the numbers?

The Morris Justice Project began in the summer of 2011 and by then, more than 4.4 million summons, 3.5 million police stops, and 1.9 million misdemeanors had accumulated in NYC over just the previous eight years, the large majority involving people of color (for more detail see Chauhan et al., 2014; Chauhan et al., 2015; Jones-Brown et al., 2013). In 2011 alone, the NYPD recorded 685,724 stops, an historic peak that represented a more than 300\% increase since 2003 (the earliest year stop data were made available). Of all the people stopped in 2011, 84\% were Black or Latinx; $88 \%$ of stops involved neither an arrest nor a summons and stops that did involve the courts were often dismissed (Geller, 2015; Schneiderman, General \& Bureau, 2013). New Yorkers were being told by the mayor and police commissioner that "stop-and-frisks" were necessary to get guns off the streets (Coates, 2013); however, guns were found less than .2\% of the time. Residents, students, and those employed within the $44^{\text {th }}$ precinct of the South Bronx, the precinct where the Morris Justice neighborhood was located, were among the most impacted in NYC. The precinct ranked $17^{\text {th }}$ in police stops, $5^{\text {th }}$ in summons, and $2^{\text {nd }}$ in misdemeanor arrests between 2003 and 2010.

Communities of color like the South Bronx had long been enduring the deleterious effects of pervasive and aggressive Broken Windows policing, sold under the unsubstantiated guise of improved public safety (Fabricant, 2011; Howell, 2015); but which publics and whose safety? This era of unprecedented incarceration and aggressive policing has turned neighborhoods, like the Morris Justice neighborhood, into symbolic and actual jails where the everyday experience of just living becomes criminalized because of the assumed potential for committing a crime (Alexander, 2012; Stoudt, Fine \& Fox 2011). Contact with police in communities of color like the $44^{\text {th }}$ precinct are largely punitive and backed up by the state-sanctioned threat of escalating violence, punishment, and potential death (Platt et al., 1982; Vitale, 2008). This contact, consisting of millions of moments, too often violent, represents a rippling web of potential punitive short-term and long-term outcomes, deep-rooted humiliation and insecurity as well as the possible residual erosion of trust and legitimacy. The structural violence imposed by Broken Windows policing had only been steadily increasing in the years before members of the Morris Justice Project began to organize in 2011.

Living in the era of Broken Windows: Our roots. Every one of us living in the South Bronx was affected by these longstanding NYPD policies and had stories of police violence and harassment. Paul remembers "they were stopping and frisking almost everybody." But the practice was so common for some it just felt like "life." This was true for Jackie's young sons who never complained to her about their experiences being stopped. "I didn't realize that they were being stopped on a day-to-day basis, asked to get against the wall, pat down and all." Fawn's son was also targeted: "the police were harassing my son and all the kids who were living in my area. But the harassment didn't stop there. The police would stop my family when they would come see me. It reached a point where my kids were a little fearful of coming outside, and I was afraid too. Eventually I moved and relocated [outside of NYC] with my children because of the NYPD. I had lived in the Bronx for 48 years." Anthony summed up what it felt like in the neighborhood, saying "we became training grounds for [the police]. Too many people were getting caught up for minor things. I did catch a charge and had to do some time. There are a lot of people in prison who didn't really deserve to be there. I met people who said, 'I got caught with a bag of weed."'

Every one of us living in the South Bronx were not only enduring, but actively navigating and resisting the heavy police occupation. Anthony was "looking for the law to work for me. I was looking for something I could do to stop [the police] in their tracks. I kept thinking, where can I get my hands on those books?" As a substance abuse counselor, Paul was standing up to police on 
behalf of his clients. For example, he remembers a time when an officer "stopped a client I was just walking with. I had to tell the police he had done nothing wrong." Jackie's son refused to "plead out" and insisted on establishing his innocence by going to trial. Both Jackie and Fawn were plaintiffs in one of the three major class action lawsuits that successfully sued the City for the discriminatory use of "stop, question, and frisk." Along with Nadine, they had also been using their phones to film police harassment of their children in the courtyard of their apartment complex. They organized an informal network of mothers who shared footage that could be used at the local precinct or the courthouse. "We wanted the police to know there were people watching over these kids and we wanted our kids to know we had their back" (Jackie). Big and small, these were profound agentic moments of pushing against our structurally violent living conditions. Together we understood our collaboration with the Morris Justice Project, as another form of continued resistance.

The desire and interest to connect with others - in solidarity and across difference - was palpable amongst us. As Anthony put it, "If we were going to make change, we needed to come from a place of knowing." We had questions that we wanted to understand from people who were living in similar conditions. What were others in the neighborhood experiencing and/or feeling about the police? What were their hopes and desires for our community? The NYPD, the Mayor, academics and other city elites were already answering these questions on behalf of the South Bronx and other neighborhoods of color across the city. Their answers were part of a political rhetoric, steeped in "objective" data, justifying or critiquing the widespread, expanding, and aggressive use of policing practices like stop-and-frisk. Missing from the political theater were the thoughts, experiences, and "data" of those most impacted by these practices. It is no surprise, then, that those of us - Jackie, Fawn, Nadine, Anthony, Paul, Prakriti and others - living in the Morris Justice neighborhood - were interested in partnering with university researchers to take control of the narrative about policing in their neighborhood and produce research from a "community point of view." But the choice to partner with university researchers with the hope of responding to one form of long and enduring structural violence, opened Bronx-based Morris Justice researchers to the potential consequences of yet another form of long and enduring structural violence - that which the academy has committed against poor communities and communities of color.

\section{The Structural Violence of Academic Research}

As academics, Brett and María had long been involved with criminal justice issues through prior participatory action research projects in prisons and with youth. By 2010, "some academics, lawyer, and organizers around the city - including us - were beginning to gather to discuss the growing numbers of stop-and-frisks, and at the same time grassroots groups like Communities United for Police Reform were organizing into a very cohesive force" (Brett). Around that time "we were hearing from lawyers practicing in the South Bronx that their caseloads were reaching crisis levels - overflowing with minor charges" (María) and "I remember exploring NYPD data and learning that police from two adjacent Bronx precincts - the $44^{\text {th }}$ and the $46^{\text {th }}$ - used physical force during $50 \%$ of their stops - more often than anywhere else in the city" (Brett). "Our concern and interests were sparked. We felt a need to collaborate locally and we already had some connections to the South Bronx through Pace Law School colleagues" (María).

Somewhere at that intersection of lived experience, relationships, synergy, luck, research, organizing, engagement, and outrage the Morris Justice Project was born. This is the genesis story of many community-university PAR projects but, of course, with university researchers comes a fraught past. From the government-funded Tuskegee Syphilis Experiment in Alabama (Jones, 1993), to the more recent exploitation of blood samples from the Havasupai Tribe (Drabiak-Syed, 2010) or 
psychologists' connections to Guantanamo Bay waterboarding torture (Costanzo et al., 2007), university partnerships come with a long and well documented history of academic abuse towards marginalized communities.

Academia, the social science disciplines, and university research involve complex communities of practice steeped in hierarchies, expectations, values, incentives, and limitations. This significantly shapes the trajectories of scholarship - what questions are asked, methods used, interpretations made, audiences spoken to - in ways that often limit deep public connection and impact (Chatterjee \& Maira, 2014). More problematic, it increases the possibilities of producing scholarship that maintains, justifies, and normalizes oppressive structures harmful to marginalized communities (Patel, 2015). It is from these institutional and disciplinary contexts that all sciences including the social sciences have had tenuous, sometimes exploitative relationships with communities of color and other marginalized groups (Smith, 1999). Research sponsored by the academy is shaped from within conditions that are often ripe for producing its own form of structurally organized violence (Walker, 2003), a legacy that follows even the best intentioned researchers when they help build community partnerships (Cooke, 2001).

The calculated risk of partnership: Our genesis. So those of us from the South Bronx were taking a calculated risk when deciding to partner with those of us from the City University of New York. A whole history and ongoing legacy of exploitation was represented in this communityuniversity partnership. All the conventions and expectations and pressures and professional norms and potential harms came with Brett, María, and their students. They represented -- in their bodies, through their privileges, and in the professional tools/logics they inherited - a source of structural violence. Indeed, early in the Morris Justice partnership these concerns were present. Fawn remembers sizing Brett and María up, "when they first came to the neighborhood I thought, 'Ah boy, we ain't gonna do too much good.' Me and Jackie talked and we were saying, 'Well I wonder how this is going to go?' I thought it was just going to be a lot of bullshit to be honest because we have tried to get so many people involved before." Nadine feared, "it was going to be a group that talked and talked and talked with no real progress out of it." And Jackie recalled, "At first, honestly speaking, I thought maybe [Brett and María] were getting grants to come out here and do these surveys to find out what was going on but they really weren't going to be interested in the neighborhood - in the individual people. I thought maybe they'd do the grant and then move onto the next project."

At our first official meeting, an open meeting at the local library where we presented the idea of the research and invited members of the neighborhood to join us and help shape it, Brett remembers, "One of the men who showed up flat out asked, "Is this going to be another project with good intentions that goes nowhere? This neighborhood doesn't need another one of those." These apprehensions were legitimate. Concerns about professional detachment and obligation, uncommitted relationships and lack of reciprocity, myopic focus and narrow utility, and the potential of misunderstanding the neighborhood all have historical precedence in university research.

Like policing, neoliberal universities also help reproduce and preserve state power and privileged interests in ways that too frequently extend a colonial project (Chatterjee \& Maira, 2014; Patel, 2015). One needs to look no further than Brett's own home institution, John Jay College, for an example. Founded as a "college of police science" that is today a "college of criminal justice," classes were first housed at the NYPD police academy and the college still maintains a close connection to educating law enforcement and advancing "security" interests (see jjay.cuny.edu/history). Criminal justice schools and related departments emerged out of, have multiplied in size, and generally benefited from as well assisted in the unprecedented growth of our 
carceral state. These institutions train the qualified workforce, house the government grants, and generate the supporting scholarship that legitimize, rationalize, and ultimately sustain the prisonindustrial complex (Oparah, 2014).

Still, maybe too naively, we resist calling universities and university research fundamentally corroded and hopelessly doomed (Morrow \& Brown, 1994). Social science, particularly when produced critically and with strong commitments to participation, can be important sources of education, understanding, and knowledge for the public good (Torre et al, 2012). Social science methods and discourse can help us dig beneath the layers of harmful dominant ideologies and the complicated dynamics of oppressive structures. The desire to systematically ask questions and make sense of answers, the desire to theorize not only what is unjust but also what could and should be, are necessary components of democratic practice and important ingredients to determining fair, just, and sustainable solutions. So despite very legitimate and ongoing reservations by those of us who live in the South Bronx, we moved forward believing our community-university collaboration had the potential to push against the structural violence of the NYPD and criminal justice system, helping us document the injustices, contextualize the policies and practices, reframe the misconceptions, and learn from our neighbors (not from politicians or the NYPD or the other so called "experts"). To this end we conducted publically oriented research (versus academically oriented research) on issues important to our lives in ways that took our deep-rooted knowledges seriously and benefited our community directly. Though neither exhaustive nor standardized, in the next section we describe the commitments, principles, and practices that, as a collective, we felt defined our attempt at public science as practiced through PAR (Torre et al., 2012).

\section{Collectively Resisting the Structural Violence of Policing through Research- Activism: The Community Commitments of the Morris Justice Project}

The first part of this section discusses what the Morris Justice Project interpreted as some of the conditions for strong and intellectually generative participatory and democratic public science. Great care and attention must be placed on what the participatory spaces of action research look like (Cahill, 2007; Stoudt, 2007; Torre, 2009). Do people in the group feel safe, even encouraged, to dissent, to offer competing perspectives, explore uncomfortable thoughts and examine hidden assumptions, to change their minds and discover new ideas? We believe our rigor and validity comes from relationships built in diverse participatory contact zones that bring differently situated people together (Torre et al., 2008), and our ongoing and rich conversations with each other and the neighborhood. The second part of this section describes our commitment to both strong research and meaningful action. Our research, through process and practice, was accountable to "home" through deeply collaborative and community engaged spaces where we iteratively explored policing conditions in the "Morris Justice" neighborhood using a range of methods. Our research was then enacted as a form of social action, advocacy, and activism through what we call "sidewalk science": a continuing presence of street actions using our research to spark critical conversations among neighbors about policing.

\section{Committing to Strong Participatory Spaces}

The Morris Justice Project took seriously learning through relationships that maximized broad and grounded community based participation. The validity and subsequent impact of our research benefited significantly from deep collaboration as a collective and ongoing close contact with other members of the community. As we designed our methods, we built "research accountability structures" as spaces of dignity, commitment, reciprocity, and understanding. In this 
way, we aimed to use our research to contribute to public conversations, that is, to continue meaningful dialogue amongst the research collective, to facilitate meaningful dialogue amongst South Bronx residents, and to join meaningful dialogue citywide amongst lawyers, policymakers, activists, journalists, and the NYPD. In the following section we lift up strengthening diverse relationships and pursuing ongoing critical dialogue as two elements of strong participatory spaces.

Strengthening diverse relationships. The Morris Justice Project brought differently positioned people across personal/social identities, institutions, and geographies together in a participatory contact zone (Torre et al., 2008) that continually sought, acknowledged, and benefited from multiple and intersecting standpoints. "People from all walks of life coming together for a common cause that will benefit future generations is a beautiful thing" (Anthony). As co-researchers who ranged from residents of the South Bronx to professors, students, artists, lawyers, and community organizers, we held a wide and varied set of expertise, experience, skills, and values. These diverse relationships to each other and to our research were conceptually and methodologically generative. Our multiple standpoints produced a "strong objectivity" (Harding, 1992) that provided us multiple ways of holding our research accountable. As a collective we embraced contradictions and unpacked areas where ideas conflicted. The tensions in our differences advanced the value of our research, analysis, and action. "If there is something that someone doesn't like we say it. We say, 'No I don't think that's going to work' or 'I don't think we should do that, maybe we should do it a different way" (Prakriti). We sought to strengthen these productive relational spaces both inside and outside our collective.

Strengthening diverse relationships inside the collective. We purposely designed the research to be flexible and open-ended to maximize the possibilities for people to more meaningfully and consistently engage, given full and complicated lives. Some of us came together at the very first meeting while others joined along the way. A new baby, change of schools, moving, work schedule, responsibilities at home, failing health, or dissertation writing were among the issues responsible for some of us leaving permanently or for a time. We structured our research collective as intentionally porous so that we could continually benefit from new energy, ideas, and knowledge. All together the Morris Justice Project has had more than 25 members that have been held together by a consistent core of 10 who provide the project with a sense of permanence, coherence, and long-term commitment. We do not assume everyone will do everything all the time, and instead our labor is distributed by interest and availability. That said, all big decisions are discussed as a group and all work is reviewed and revised by the group. The project has sustained its vitality, diversity, and purpose through these intentionally absorbent research spaces.

Respectful and responsive research spaces are a key part of maintaining the diverse and layered relationships necessary for meaningful participation, wherein everyone in the research collective feels a sense of ownership and responsibility towards the direction of the project. "We voice our opinions and we also listen to each other" (Jackie). Paul joined the Morris Justice Project after the collective had been together for several months: "When I first joined, the group really listened to me. I was actually able to voice my thoughts and the key thing was, the group accepted my ideas and even started to work out ways to incorporate them into the survey. The group was pretty much in place already but I helped broaden the brainstorming piece. I felt like I was not only speaking for myself but for my community. I was a channel, a mouthpiece so to speak".

Acknowledging that we are differently situated but also hold shared fates, members of the group made a growing commitment to each other. We brought together our varied/changing differences, similarities, expertise, and knowledge, and built a set of reciprocally minded relationships, in solidarity, now lasting more than five years. The content of our work - intimately lived by most in the group - was often violent and complicated. It was painful to communicate and 
painful to absorb. The stories we shared and the data we collected were hard. The problems we sought to change were large and structurally entrenched. Because of this, our relationships as coresearchers needed to be based in mutual care and understanding.

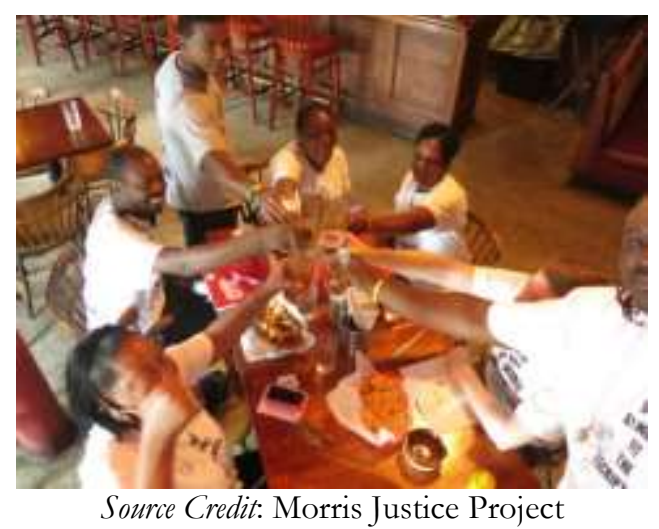

Our relationships began through our collective participation in the research. However, as María described, "our relationships grew like intertwining vines." "We worry about each other. That's how much we've grown to care for each other" (Jackie). We exchange frequent "good morning" and "happy birthday" texts and miss each other when we have not met in a while. We've watched movies and attended community forums together. We've held surprise baby showers, organized birthday parties, and attended funerals together. We've been in cramped vans for long road trips and on flights to other states. We have experienced first times together - first time speaking in front of a large audience, first time flying, first time eating pulled pork, first time publishing. We have been together through arrests, trials, house fires, and visits to the White House. We have shared beer and Long Island Iced Teas and toasted - to each other, to health, to safety, to secure housing, to better schools. Various circumstances brought us together but "now we are family" (Fawn). "We're a family of a different kind" (Jackie), an extended family forged through anger towards police violence, maintained through doing empirical research and nurtured through mutual affection; we are a family of researchers and activists who want something different for our children, our loved ones, our neighbors, and all NYC residents.

Strengthening diverse relationships outside the collective. The relationships we cultivate inside the Morris Justice Project extend, by design, outside the group. Our work travels beyond the group, influencing and influenced by creating participatory circuits. Our families, friends, neighbors and co-workers offer advice and direction. "My son sometimes asked me, 'Are you going to meet with MJP tonight? Because last night I was thinking...' When he gives me ideas about the project I jot them down." (Paul). "My daughter did a project for school regarding policing and the Morris Justice Project. She used our survey. She chose certain questions to ask students in her class" (Fawn). "Sometimes I'll see a neighbor with a Morris Justice Project t-shirt or button on the bus or walking down the street" (Jackie) and sometimes "when I'm wearing our t-shirt, people will stop me and strike up a conversation" (Anthony). Our project has spread throughout the neighborhood in ways that helped our collective make sense of the research and helped our neighbors make sense of the conditions they're living.

The diversity and depth of our relationships inside the Morris Justice Project created a strong foundation to nurture relational spaces outside the group. We expanded our connections to include people who have a range of important expertise to enrich the quality and impact of our work. We established relationships with attorneys and other legal advocates to assist with research 
design and analyses as well as help conduct legal-oriented actions (e.g. know-your-rights trainings). And recognizing that our collective, while diverse, was a small minority of the $19,000+$ people who lived in the "Morris Justice" neighborhood, we organized a multi-generational advisory group of neighborhood young people, clergy, community organizers, store owners/managers, lawyers, the librarian, and others who helped us reflect on our survey draft and overall research design.

Our ethic of cultivating relational spaces throughout our project also shaped our research strategy for sampling. When we walked block to block to distribute our community surveys, we did not consider ourselves "in the field" or talking with "subjects" - we were in our neighborhood and talking to our neighbors; we were in our home trying to learn with other people in their home. Our approach was conversational and the sidewalk dialogues that emerged frequently lasted longer than it took to complete the survey. By the end we held 1,030 community conversations. "Residents had all types of reactions to the survey questions. They would stop and they would start up a conversation right there and then, and you think oh shit this is for real" (Jan). "I remember this one older man just wanted to tell me his story about when he was stopped. I didn't know where to record it except in my memory and in my head" (Prakriti). "You would get in this long conversation after the person read through the survey. You really realized just how many people had gotten stopped and how they felt about it. It happens all over" (Nadine). We shared these stories with each other in debriefing sessions and noted the reoccurring themes for future analyses. Our survey produced moments of community engagement where a sense of connectedness, validation, and solidarity was established.

The relational ethic of our research honored expanded versions of expertise. This was operationalized by threading these points of contact - whether brief or extended moments - in ways that were both respectful and reciprocal. This research approach is different than mainstream approaches where research remains disconnected in order to "protect" a "neutral" stance. Our research by contrast was not designed for distance - it was designed for closeness. It was not designed for a few homogenous people or a few homogenous ideas; it was designed to include many people with many perspectives. We believe that it is in the richness of these multiple and varied perspectives that the necessary depth, validity, and accountability of our data and interpretations are produced. And so it was with purpose and deep care for the neighborhood, that we did not separate ourselves from the places and people where the data were derived. Our meetings were in the neighborhood, our data were analyzed in the neighborhood, our ongoing actions were held in the neighborhood. We did not want to "extract and leave." Instead, the intent was to be as accountable to the neighborhood, and too as many members within the neighborhood, as possible. We believe it is through these diverse relational spaces - inside and outside our group - where our deepest understandings are reached, where we gain knowledge beneath the surface, where we find the most meaningful analyses, and where our most valuable impact emerges.

Pursuing ongoing critical dialogue. We are not naïve. We do not wish to underestimate historic structural oppression nor overstate the power of PAR. Participatory action research is not a panacea to the fundamental problems of the university nor can it crumble the oppressive structures of state sanctioned police violence. It is a path that offers some dignity in the pursuit of knowledge, some protection against the harms of university research, and some strategies for collecting information useful in the struggle against injustice. Participatory action research is a set of ongoing moments, a process, with an explicit commitment to centering the knowledge of those most marginalized, to confronting privilege, to uplifting and negotiating power among people who are differently situated within intersecting systems of oppression. Throughout this process, we cultivated deep relational spaces to engage in meaningful conversation, to think critically and unpack the sensitive structural violence in our lives, and to practice what Sandoval (2000) calls, the 
"methodology of the oppressed." This ongoing critical dialogue bolstered the quality of our work by facilitating accountability and productive tensions.

The accountability of ongoing critical dialogue. Structural racism is one of the foundations for why the Morris Justice Project exists and conversations about race and racism were woven into all of our interactions and everything we produced. Whether explicit or implicit - as outrage, as motivation, as humor - race was in the foreground and background of our work all the time. Holding ongoing and critical dialogue has helped us to unpack the racial assumptions we operate under. For example, at the courthouse supporting her family members, Fawn felt uncomfortable with a nearby group of young black men and told the local officer to "watch out for them." It reminded Prakriti of a family member who recently would not open her purse at the mall because a man of color was standing nearby. Moments later it became clear he was waiting for his family to arrive. She used this example to theorize how deeply connected safety is to assumptions of crime and race. Reflecting on this story and others in our group helped Fawn to realize the irony in her own story. The expected link between race and crime are so entrenched in all of us and require constant vigilance. As a black woman, Fawn had a "feeling" that the young black men might be up to something, when in fact, they were really just standing around, probably waiting, the way she was. It did not take much for Fawn to recognize how her assumptions about the young men were connected to the type of profiling the police were repeatedly engaging with her own son, who has endured a great deal of police targeting and abuse. Through the process of this work, we have helped each other stay accountable, recognize that we are not exempt from reproducing the very discrimination we hope to change, and appreciate that we can all be seduced by assumptions that need to be checked, unpacked, and reframed.

Sometimes, the implications of our differently empowered racial positions were most prominently revealed when traveling to present our work together as a collective. For example, when Jackie, Fawn, and Brett were traveling home on the train after presenting at a White House Forum in Washington, DC, a person, not assuming they were all together, wedged in between Brett and Jackie/Fawn as they sat down. "When Fawn started talking to me, I remember the person looking up from his magazine with a brief sense of surprise" (Brett). In these actions and momentary glances, a long, oppressive history of who-belongs-together is exposed. This certainly applies to academics, especially when "community" is approached as exotic, homogenous, damaged, and in need of saving. "I remember early on thinking how different it felt for me as a white researcher to present our project alone versus collectively as a group. Alone, I found myself describing the conditions of the South Bronx in ways that seemed one-dimensional, uncomplicated, deficit potentially reifying for the audience the stereotype of ghetto. As a group, I found myself more conscious about presenting the harms and the vibrancy, the agency, the resistance. It was a good lesson for me in the politics of representation and the accountability of collaborative spaces." (Brett)

As Morris Justice researchers, we have found ongoing ways to be reflexive of our values and standpoint, of our history and contexts, and of our intersecting power and structural oppression/privilege. We purposely created processes within our relational spaces to thoughtfully explore alternative interpretations, include differing perspectives and unfamiliar "outliers." Unusual or unexpected findings were deliberately sought and the perspectives of those critical of the police reform movement were explicitly "brought into the room," including people who held both conservative and radical critiques. In other words, despite our activist stance, we were committed to allowing the data to illuminate and surprise us, even when what we found conflicted with our assumptions. This, after all, is one of the primary functions of research. Why do the research if you already know the answers? 
To help expose our taken-for-granted expectations of the data and hold ourselves accountable, we designed collaborative analysis activities. One such activity involved handing out a worksheet with survey items to the left and blank spaces on the right. We asked each other to write down what percentages we thought we found. What percentage of our survey respondents experienced physical police contact in the last year? What percentage were asked to move by police? Some of us overestimated and some underestimated, but as we juxtaposed our guesses (our assumptions) with the survey responses from over a thousand neighbors, we were forced to unpack our predictions, to confront counter stories in the data, and propose further analyses (e.g., "well, my percentage probably would have been right if we just looked at young men!' Jackie).

The productive tensions of ongoing critical dialogue. The data we produced through our survey or other methods were personal. The convictions we held of the data were rooted in extensive experience. Engaging the data through activities evoked passionate conversation. Ours is a research collective that experienced misunderstandings, frustration, and disagreement - and we've found these tensions to be very productive as a participatory research group. Conceptually, tensions that emerge from the clash of ideas, or what María calls "choques", can illuminate our differing assumptions and values about what is and what should be (Torre \& Ayala, 2009). These are often implicitly held but not explicitly stated until disagreements emerge out of discussing data. Some of our most important tensions - ones that have been most impactful to our analysis - have revolved around our understandings of police reform versus police abolition or criminal justice reform versus a world with no jails. For example, we debated interpretations of data and political activism that demanded that police stop going after the "small stuff" in favor of the "serious crime." For some, this was exactly right. For others, the social construction of "small" and "serious" crime in communities of color needed to be unpacked as part of the same structural violence produced from the criminal justice system. We debated the controversial state-encouraged practice of parents requesting a "PINS" ("Person in Need of Supervision"), an early-intervention program designed for "uncontrollable" children whose repeated behavior (e.g. skipping school) makes them (and their parents) vulnerable to the criminal justice system. Some parents in our group had been advised by school officials to enroll their children as the lesser of two evils, that is, as a strategy to gain resources/control when the alternatives were more severe and other options unavailable. And yet, it is also a "master's tool" (Lorde, 2003) that surrenders parental control and invokes the very punitive system we are fighting to change. These were knotty but productive conversations that emerged because of our relationships, that further strengthened our relationships, and that helped construct shared knowledge amongst us.

Other forms of tension, though ultimately productive, involved relationship stumbles. There were times we let each other down. After the Morris Justice Project finished collecting surveys but before we began statistically analyzing them, there was a four-month gap where a few in the group were helping enter the data into SPSS while others felt completely disconnected. "In between finishing collecting surveys and our next meeting we hadn't spoken in a while. Nobody had really communicated with each other about the research. So I started thinking maybe they [Brett and María] got that grant they were talking about, and left us sitting here. So when we did get back together that is what I told them. I said how I felt and that I knew Nadine and Fawn were thinking it too" (Jackie). This anger was legitimate and based in a long history of racial and class-based exploitation of communities at the hands of university researchers. "Everyone was so frustrated. I felt so bad and very apologetic. They thought we took the surveys and ran - made a career off of their labor. It was unexpected because it was the very opposite of why we were doing the work. And ironically, over that gap, I never felt busier with the project." (Brett). "I was helping enter the surveys along with others and would see Brett and María regularly. It was a busy time but it was at 
the university and not everyone was involved. I had free time during the week to help and probably had a better sense of everything. There was miscommunication" (Prakriti). "The conflict ended up making us closer and our project stronger. After this, we exchanged numbers and we agreed that we all have to be more connected, you know, communicate more. Now we communicate, over group texts, or phone calls, or just 'hey tell your son happy birthday;' you know we needed to be on a personal level with each other. This helped us become friends and even I think a family" (Jackie).

\section{Committing to Research and Activism}

The Morris Justice Project has become a space for hope and a space to imagine change and pursue collective action but it began as, and always remained, a project about strong research that was directly accountable to the South Bronx community and committed to police reform. We wear many hats: activist, educator, learner, community organizer, artist, designer, web archivist. However, we are fundamentally a research project. The pursuit of research - to ask important, locally relevant questions and then seek answers among neighbors - was what originally organized the group. It was what Appadurai (2006) calls "the right to research" which grounded the project ethically; the right for people, even if not academically trained, to be researchers engaging critical questions of the conditions they intimately live. We believed that the validity of our research and our ability to produce meaningful action was heighted when those most affected by police were central in determining the questions and analyzing the answers. We wanted to speak back and even counter some of the NYPD's claims with our own community-grounded data. In this section, we turn from a commitment for strong participatory spaces to how we used those spaces to employ strong research-activism by being accountable to "our home" through inductive and exploratory collaborative analysis and a commitment to action at multiple scales.

Accountable to "our home." Entire communities of color are targeted, harassed, and assumed suspicious simply because their neighborhood is considered unsafe (Stoudt, Fine, \& Fox, 2011). Some say this is a small price to pay for safety. That didn't seem right to us but, as Anthony argued, it is important that "we come from a place of knowing." As a research collective, the Morris Justice Project decided to use a range of methodologies to systematically study the South Bronx neighborhood in which most of the group lived. While this area has a long, problematic reputation as a bad, dangerous ghetto, it was understood by most of us as "our home." "Calling something safe or unsafe is usually for the benefit of outsiders not for insiders" (Einat). We wanted to resist and challenge the stereotypes imposed on us by outsiders. "Yes, schools are an issue and jobs are an issue, but it's also true that people in the Bronx really like their neighborhood. You can walk down your block and say hi to everyone" (Cory). "I enjoy the neighborhood. It is not the neighborhood, it is what happens in the neighborhood. It is not a bad area, it's just that the police were harassing the kids and it got overbearing." (Fawn). "This is our home. I have met a lot of different people in a lot of different areas. All different types of people who have been through different things. It's beautiful" (Jackie). This research provided an opportunity to reframe and complicate representations of "our home" by holding the work directly accountable to "our home." 


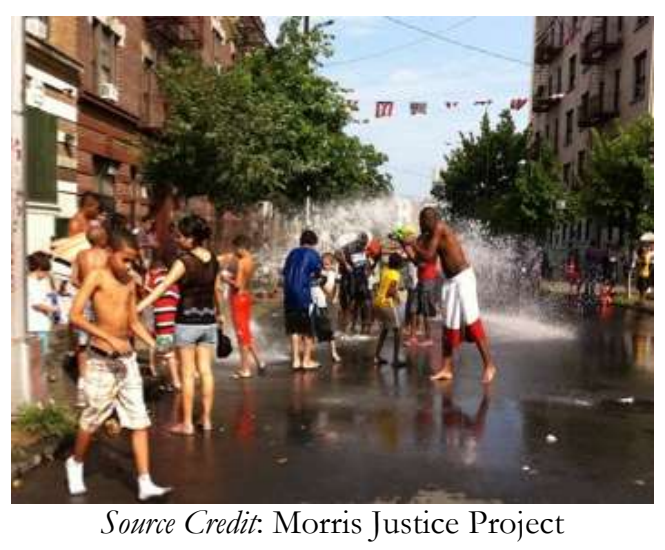

Our work deliberately had broad and multiple audiences that initially included policymakers, lawyers, and even academics. However, the primary focus and therefore the primary responsibility for the Morris Justice Project was to those who lived, worked, and/or went to school in a 42 square block radius of the South Bronx, just east of Yankee Stadium, and bordered by railroad tracks, large streets, and public housing. This is not a geographic area defined by a precinct or census tract or developers. It is an area defined by members of the project who live in the community as to where they make home. While the "Morris Justice neighborhood" has much in common with other heavily policed, poor, and under-resourced neighborhoods across New York City, it also is unique and our commitment was to take seriously these particulars. The Morris Justice Project organized multiple spaces and activities that facilitated this accountability. In this section, we describe how "our home" was intentionally and fundamentally "baked" into the research design. It was a chosen priority that began early as a survey/interview development and sampling strategy and continued as an oscillating research process.

Our home as a chosen priority that began early. Most social science research is accountable somewhere. Academic research is typically accountable to other academics. The pressure for university researchers to publish and present in traditional venues is real and so is the ongoing accountability to department heads, provosts, yearly reviews, tenure/promotion committees, advisors, journal/book editors, and other academic audiences. However, the Morris Justice Project decided as a group that engaging in academic discourses would not be a priority. Our first priority was to have our work available to and held accountable by our South Bronx neighborhood and, additionally, the groups involved with police reform activism across the city. Given the growing intensity of the police reform movement at the time - all that was happening through grassroots organizing, lawsuits, and policy - it seemed that communicating our findings with other academics was not as urgent nor did it hold the greatest potential to effect change. This commitment, while the right one for the project, was challenging for those of us located in the university who were seeking tenure, pursuing funding, going on the job market, or hitting other milestones along their graduate training (e.g. completing a dissertation). The type of impact we collectively sought and eventually had outside the academy was often not the kind of impact most valued inside the academy (e.g. impact factor, citations). Nevertheless, by divesting in university discourse we gained greater momentum to concentrate on our community efforts.

Holding research accountable to community is not something that happens as the final phase before completing a project; it begins at the very inception and then continues throughout. It starts with strong and diverse participatory spaces that are conducive to critical conversations and caring relationships. From there it extends into constructing grounded research questions/methods in order to gather useful information for deeper understanding and future actions. In other words, it creates participatory research spaces where community members can effectively contribute their 
expertise and offer their knowledge. For the Morris Justice Project, this started that very first summer in the basement of the local public library during what we called our "research camp," where we engaged deep conversations, began unpacking our assumptions, and educated each other about policing. Our expectations varied, though it was nearly everyone's first "real" research project. Some "didn't know what it was going to be like - a clean slate" (Fawn) and others "took research methods in school but assumed it would be more on paper and less outside, walking around, asking questions, taking pictures" (Prakriti). All of us believed this version of community-engaged inquiry "is how research should be done because you are not just getting one-sided information: you have the opportunity to speak with both sides and the information is coming from the actual people who are affected by the police" (Paul).

Our home as a survey/interview development and sampling strategy. During the research camp, we learned that research was fundamentally about asking questions and seeking answers. Many of us were surprised that we already had some of the skills needed to become an effective researcher - we already were asking questions, we already had theories, and we already were close listeners and observers. We spent time describing what it was like living in the neighborhood, shared personal stories of struggle and joy, and learned about our similarities and differences. Our assumptions about each other, the issues, and research were challenged and complicated. Different guests came to educate us on the criminal justice system, our legal rights, NYPD policing policies, and statistics. Gradually, we recognized our working theories and began reframing the themes of our discussions into interview questions and survey items. After about $20 \mathrm{drafts}$, our survey was finalized, containing questions about experiences with and attitudes towards police as well as perceptions of the neighborhood. We also wrote a set of open-ended focus group questions covering the same topics as the survey (see Stoudt, 2012, and Stoudt et al., 2016, for more on participatory survey design). "The survey emerged organically from the group's ideas" (Prakriti). "It was cool knowing that we really created the survey from the bottom up. We just created it from scratch as a group. It wasn't just some symbolic activity - it was real" (Jan). An academicallyoriented survey might, for example, use standardized scales with strong alphas to facilitate publication. For us, the ambition was to create a community-oriented survey (among other methods) from grounded expertise, unhinged by some of these academic concerns unless it served our larger purpose. It was not easy. "Trying to get the survey itself done, to form the survey, to get the right questions, to find out what you wanted to put in there, and imagine how people would respond to it. That was kind of tough. We're just a few people trying to represent 42 blocks" (Jackie).

We were just a few people trying to represent the neighborhood, which is precisely why we first sought accountability by organizing a community advisory group and then sought input from our neighbors by systematically distributing the survey block by block. Our "homegrown" survey represented a document packed with our burning questions, assumptions, and concerns; it represented a first step in our attempt to start community conversations. "Handing out the survey was interesting. I could tell people it was something that I helped make. I had my feelings about how things were going, and now I could see do you agreed with me? What do you think?” (Jackie). We sampled by creating a relational space; an on-the-sidewalk, pen-and-clipboard process that encouraged neighbor-to-neighbor engagement. "We were surveying up and down each street, up and down each block. I loved it. You got to meet different people and people got to meet you. Just from seeing you on the block and maybe just waving. Then they know your name. You'd be surprised how many people were interested. And you got to hear other people's battle stories of the street" (Jackie). It was important that those of us who lived in the neighborhood "put their stamp of approval on the research and claimed credit for the research. We made it clear that this was coproduced and accountable to the people who live right here - not the university, not the NYPD." 
(María). "When we were handing out the surveys, people walking by looked at me and they knew I wasn't trying to sell them anything. They knew I was from the community. I think it would have been different if Brett or María tried to do this alone. People would have seen them differently" (Paul).

Our home as an oscillating research process. The Morris Justice Project initiated and maintained neighborhood accountability through an oscillating research design that intentionally sought expertise from our immediate research group and the larger community. Internally, we developed our survey and focus group questions and then created an external advisory group to get feedback. Internally, we finalized the survey and focus group questions and then externally we sampled the neighborhood. Internally, we analyzed our data and then, once a set of preliminary analyses emerged, we sought external interpretive help from residents in the neighborhood through a "community analysis" process. And so on. "It sort of pulsated - critical conversations in the group were followed by critical conversations outside the group, then back to us and out again. Seeking answers, getting answers, asking new questions and repeat - that was how our project worked" (Brett).

Our oscillating participatory design was deliberately structured to ground and strengthen our ongoing connection to the 42 blocks as well as enrich our iterative, exploratory analyses. We felt it made a difference in how the Morris Justice Project was understood by the community and improved the overall quality of our research. "I think the neighborhood has changed towards us. When we were giving out the surveys, people were like questioning us, "Why are you doing this? How is this going to do anything?' Then last summer when we did the sidewalk science some people recognized us, 'Oh you guys were the ones giving out the survey.' And, 'Oh, you're still here?' We see people wearing our t-shirts and buttons. Residents have 'tweeted' our events. I think a lot more people are aware now and I think they like what we are doing. We've grown neighborhood trust" (Prakriti). This is our best hope for the work: research with and for the community.

Inductive and exploratory collaborative analysis. The Morris Justice Project believes that research most useful for activist, political, and legislative agendas requires a commitment to strong social scientific practice and to creating research that can withstand critique and fill gaps in knowledge. As a result, we closely considered methodological validity (though not necessarily mainstream versions of validity), meaningful questions (research questions and survey/interview questions), sampling (who to collect information from and how to collect it), and analysis (collaborative analyses and pursuing outliers). Research for the Morris Justice Project was not an exercise in simply reproducing what we already "knew" nor was it about producing data for a specific organizing strategy or to further a particular advocacy campaign. Our research was a sincere pursuit of new knowledge on issues we were passionate about. We genuinely wanted to learn about the neighborhood and this took the form of an iterative, exploratory, open-ended research process that very much aligned with qualitative approaches (Hesse-Biber \& Leavy, 2003). We even framed our quantitative work as an interpretive, subjective, and contextualized exercise (Byrne, 2002). Our entire research process was intended to be as inclusive and accessible as possible so that everyone could offer their knowledge and skills to the effort. Multiple methods were employed with the expectation that it would improve the quality of the research (Creswell, 2003) but also, from a PAR perspective, improve the potential usefulness and impact of the research. As strategies were built for participation throughout, no attempt was made to value one method or kind of data over another, whether quantitative or qualitative. Instead, our ambition was to understand the issues as deeply as possible by continually threading multiple ways of knowing into an ongoing whole. We highlight in this section our collaborative analyses of the survey as well as our analysis across multiple data that ultimately was done with and for the community. 
Collaborative analysis of the survey. Our commitment to participatory exploration can be illustrated by looking closely at our survey analysis. Once the surveys were collected, we entered the data into SPSS and began analyses as a collective. Those of us living in the neighborhood had intimate knowledge, expertise, and theories about what the numbers might mean. So we analyzed the data collaboratively using a set of participatory analysis techniques that Brett calls "stats-naction" (Stoudt, 2014, 2016). Data, numbers, survey items, graphs, crosstabs - all took on a different significance because they were derived from OUR survey within OUR neighborhood. "To me the stats-n-action part was so amazing because at first, never doing this before, and somebody throwing a graph up there, a chart on the wall and all you see is $65 \%$ of this - you might see it was black, you might see it was Hispanic or an age thing but really, all it looked like was just numbers and a chart. NOW, I knew what that number meant. I KNEW that percentage, they were people in my neighborhood! Because it was my neighborhood that we did the research in - a 42 block radius - I knew that little kid, I watched him grow up. And I knew when he hit 12 or 14 that he was one of the young men in the 12-16 or that 16-21 group we aggregated. I knew somebody in each group we looked at. Even I fit under a category. It wasn't just a chart now, I was somewhere up in there. $M y$ name was up there - you just can't see it" (Jackie). The strategies for analysis varied but were intended to be interactive, flexible, inductive, and driven by conversations with the group. "I remember when we were in the library and Brett was throwing graphs on the wall and we would ask questions, wanting to know how the numbers changed when we looked at different groups - can you add women in that? Can you add children?" (Cory). This collaborative approach to quantitative analysis helped us understand the neighborhood beyond our personal experience. "I was going through stuff [police harassment] with my son but I didn't know so many other people on the other side of the gate [of my building's courtyard] were going through it too. If I didn't have sons, I wouldn't know any of this. So seeing those percentages showed me what others were going through" (Jackie).

Our ambition was to cultivate fundamentally collaborative interpretative spaces throughout the project. We were reminded of the value of these spaces when we stumbled, at first, in our attempt to analyze the open-ended survey question, "What would you like to say or ask of the police who patrol your neighborhood?" Over 800 respondents answered this question - too many responses for everyone in the project to read and discuss. Instead, we developed a method we called "micro coding." A few of us took responsibility to read all of the responses and thematically organize them into smaller primary codes (from over 800 responses to slightly over 100 codes). Then, we created an activity to facilitate a consolidation of the 100 codes into 10-15 higher order themes. At first, we anticipated that everyone in the group would attempt the thematic coding on their own and then we would reconcile differences that emerged in the group through discussion. "We had previously done a fair amount of collaborative thematic analysis with data gathered through other methods, so it seemed speeding up this round of analysis with everyone doing some at home made sense" (María). However, the group struggled with this as an individual exercise, and soon texts poured in asking for a group analysis meeting. We were accustomed to collaborative analyses, so we revised our process to reflect the interpretive culture we found most comfortable. "Once we went from being alone to splitting into a number of smaller groups - the exercise flourished. The themes came alive. The room got loud. Ideas were flowing" (Brett). 


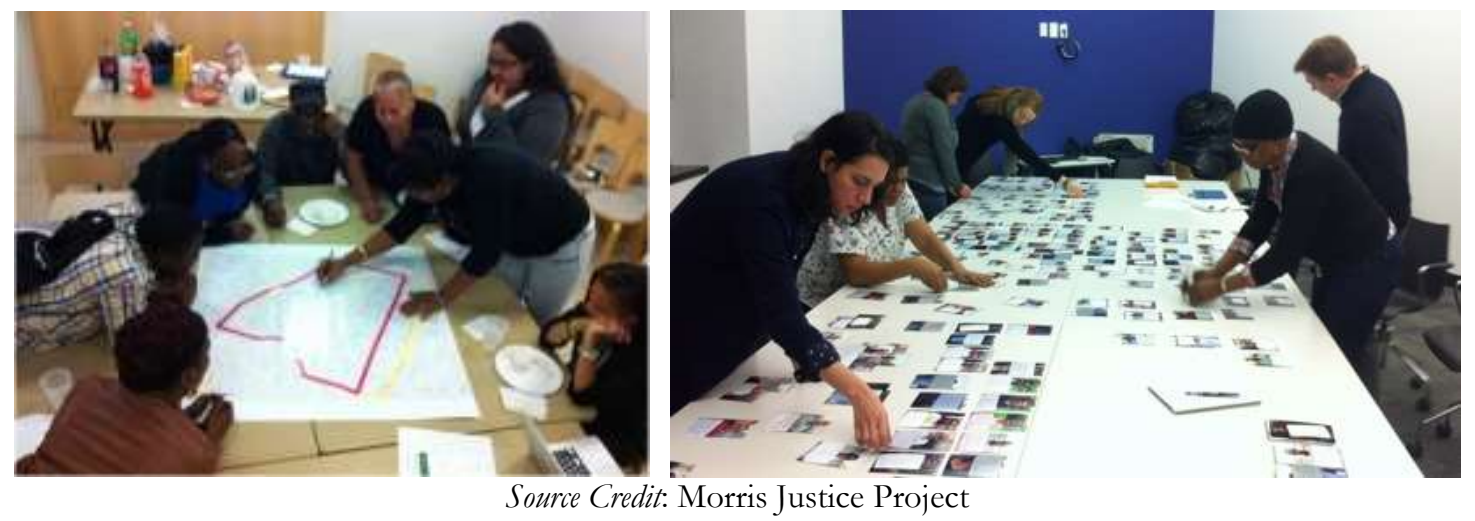

Collaborative analysis across multiple data. In addition to analyzing the data produced from our survey, we analyzed NYPD data mapped onto the 42 blocks of our neighborhood as well as NYPD data mapped throughout the city. We used this official public data to reframe and speak back to the dominant narrative, questioning its validity and comparing it against our interpretations. Juxtaposing our research with public datasets, we "come to the table with data" (Brett), demystifying the power of evidence-based policy and "earning" a spot to speak back a counter story using the dominant language of our neoliberal institutions. "I definitely learned the issue is bigger than the Bronx. Data can be manipulated sometimes. When you look at the police data and then the data that we collected, you see disparities. I've learned that not everything is actually the way it appears.

Because even when we took some of the NYPD's statistics and we analyzed it, we realized this can't be right. What has always been very surprising to me is the amount of time people were stopped by police versus how seldom people have actually committed a crime, or a weapon was uncovered. Those numbers are very off. Somebody has to realize in the police department that something is wrong here and it needs to be corrected as soon as possible. They have to open their eyes and take light of the data that we have provided" (Paul).

We also collected and analyzed qualitative data from a series of methods including community safety photographs, focus groups, and interviews. Analyzing it all together through the multiple methods helped us draw connections, go deeper, strengthen our sense of validity, and come to new ways of understanding our data. "I was reading the answers of the open-ended questions in the survey and then looking at the written responses from the community safety pictures. The survey responses were collected a year before the pictures but there are a lot of similarities across the different data, like people saying they want respect. I wasn't expecting to see these connections. It suggests things still haven't changed and the issue is as relevant today as it was a year ago" (Prakriti).

Collaborative analysis with and for the community. Our multi-methods data gave us varied results but preliminary patterns definitely emerged. It was then time to move these stories out of the Morris Justice research team and into the neighborhood through what we call "community analysis." We designed a community analysis process to seek out residents' interpretation of our preliminary data. A booklet was created that laid out a set of four broad questions and data that related to those questions. We took these booklets to the streets and held conversations on the same blocks where we had sampled. These were sincere consulting conversations. This was not a moment to educate, it was a moment to gain interpretive insight into our data from another set of perspectives. The conversations helped us reconcile some of the data we were not sure how to interpret (e.g. the frequent endorsement of middle values for some survey items). The interviews were recorded and the interpretations were incorporated back into our collective analysis.

Through our multiple methods and our iterative, oscillating, exploratory process that moved between our group and the larger community, we ultimately agreed upon a first set of important 
results. We felt an urgency to produce something that would speak to the lawyers, politicians, and community organizers working towards reform, and most importantly, that would speak clearly and directly to the 42-blocks from where we gathered our data. We wanted to present our findings in an accessible and interesting way but one unlike a flyer (that might be thrown away) or a formal report (that might never be opened). Given all of these considerations and inspired by the fashion of young men in the neighborhood, we decided to produce a postcard sized "back pocket report" that unfolded into a colorful informative poster. We could distribute it on the sidewalk and it could slip easily into pockets rather than garbage cans. "We made a short list of our key stats and quotes to include. We worried that people might not want to read a long report. But if it was something they could put into their back pocket and not throw away, then that might spark conversation. We hoped it might help inform them about what other people think in the neighborhood" (Cory). "The back pocket report let the community know this came from you all. Without your input we wouldn't have had this. Remember last year when you took the survey - okay - so now you get to see what we learned" (Jackie). In this way, our back pocket report was not only a localized strategy to communicate our findings, it was a strategy to continue facilitating the community conversation on policing, an action that grew from our research.

Commitment to action at multiple scales. Given the iterative, exploratory design, it is not always easy or meaningful for the Morris Justice Project to find clear distinctions between what is research and what is action, nor is it the case that research always precedes action. For example, we created opportunities to educate others about local resources during the process of gathering surveys in the neighborhood. Similarly, action-oriented activities to distribute the research findings in the neighborhood also doubled as moments for further data collection. Social research as a process can be a form of action and some actions can produce valuable information. Our clear and constant commitment, however, was not only to conduct strong research but also to braid research and action throughout the process of our work.

The Morris Justice Project was intentionally designed to engage deeply in a small section of NYC that was highly impacted by the city's aggressive policing policies, so that the research and action would always be grounded in a local community even as it spoke across the city. Our research collective held three simultaneous commitments in solidarity with the citywide police reform movement as they challenged the NYPD, the city administration, and the state government: finding strategies to engage residents in the data produced by their neighborhood; findings strategies to amplify the stories and concerns of residents in the neighborhood out across the city; finding strategies to bring information back to the neighborhood from others across the city. This researchaction design allowed for the collection of large amounts of information and the direct delivery of that information back, in a reasonably comprehensive way through education, neighborhood activism, legal support, and relationship building with local residents and community organizations. At the same time, this design allowed for the collection of information that had relevance beyond the local and helped us establish strong, reciprocal connections with a host of citywide activities including grassroots activism, legislation, and lawsuits. The following are some of the researchactivism pathways using what we call "sidewalk science" as a set of strategies to reclaim our "right to the city" (Mitchell, 2003). This section describes how we used sidewalk science as action for the neighborhood and with the neighborhood, through an emergent process that can be used to challenge privilege and speak out from the neighborhood in ways that support and contribute to policy change.

Sidewalk science as action for the neighborhood. "Sidewalk science," a series of interactive installations we held on the streets to both share and collect data, represents perhaps our most significant attempt at research-oriented activism as a way to directly speak with the 
neighborhood from which the data were derived. As an act of both solidarity and education, we hoped it would broaden the social understanding of where one lives while deepening political analysis and engagement. Sidewalk science offered ongoing opportunities for residents across the blocks to learn about the project's findings, find themselves in the neighborhood data, gain awareness of the legal/political activities that emerged out of the police reform movement, discover ways to get involved and, most importantly, to engage in face to face discussions about policing and safety. These were moments of public dialogue and community solidarity linking a diversity of perspectives, people, ages, and experiences.

One example of sidewalk science involved the Morris Justice Project's partnership with a roving activist art group called the "Illuminator." Using a large projector fastened to the roof of a van, the Illuminator beamed our survey findings, as well as a documentary short and advocacy clip about stop -and -frisk, onto the side of a 20-story public housing building located in the neighborhood. The event began with a drumming and dance performance by Bambayo, a local Afro-Latino cultural group, to gather an audience and ended with a "know your rights" training that spurred a vibrant discussion amongst a sizable crowd. Our findings were displayed in the form of an open letter to the NYPD that used both our qualitative and quantitative data to describe the level of police harassment in the neighborhood and asserted that this was a community that residents cared about and called home. The projection was cut short by the NYPD near the end of one of the film shorts that followed our open letter.

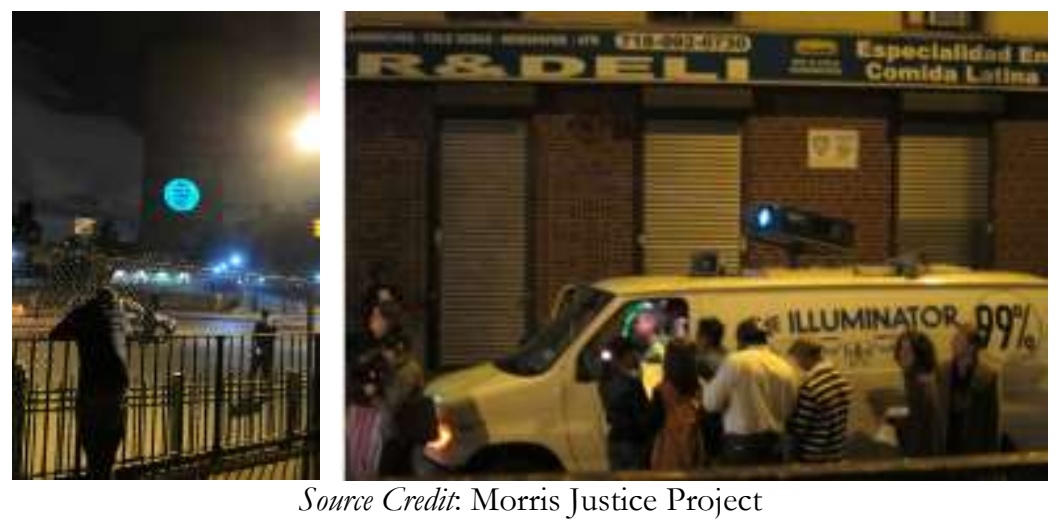

"The illuminator, that was like calling batman, you had to see it! When they put the big light with the round circle. We were out there letting the neighborhood know in bright lights what we were about, what our survey was about, what the outcome of the survey was, what the people gave to us. And when we passed the brochures around letting everyone know what the survey was. And our letter shown so large on the side of the building, we're narrating it ourselves, taking turns over the loudspeaker. We had dancers out there and it was right in the heart of my neighborhood. Right in the heart! People were getting off from work, looking - you couldn't help but stop. You had to STOP. Even the police had to STOP. LOOK. And it made such an impact that we had people from downtown involved - it wasn't just Black and Spanish people, it was White, it was different nationalities, that stood for the cause. These are people who didn't even know who we were, but they came out to back us up. They came to stand up for us and that some of us in the neighborhood feel like somebody does care" (Jackie). "It brought out the community first and then it brought other people that came to support us. And it brought the police out" (Nadine). "The police showed up [from two precincts and with six empty police vans] and they tried to stop us, and that confirmed even more the issue we were studying" (Prakriti). "The Illuminator - that's really how you have a conversation with people - that was a public conversation" (Cory). 
Sidewalk Science as action with the neighborhood. While the Illuminator was a single event, each summer/fall we also held ongoing sidewalk science sessions over several months in different sections of the neighborhood. Similar to the sampling strategy used to gather surveys, we systematically chose representative street corners throughout the neighborhood and set up multiactivity "stations." For example, during the first summer one station provided a timeline of the project that displayed our purpose, research, and action activities. Another was filled with educational information to take such as the pocket report, flyers about the relevant lawsuits/political activities, "know your rights" pamphlets, ways to get involved, and voter registration forms. A third station involved a large map of the neighborhood showing the number of recorded NYPD police stops from the previous year by street and street corner. People passing by were asked how they made sense of the information in the map and were encouraged to write their responses directly onto the map. And because conversations on the corners regularly brought up questions of safety, we created a fourth station that asked, "What does community safety look like?" Residents wrote responses on a whiteboard and then were invited to pose for a picture holding it (in whatever manor they chose, revealing or hiding their faces). Two photos were printed on the spot, one for the person and the other displayed on a "community safety wall" that grew with every sidewalk science session. We gave t-shirts and buttons that displayed our data to all who stopped and we had chalk that children and others used to mark up the sidewalk with data, thoughts, and desires.

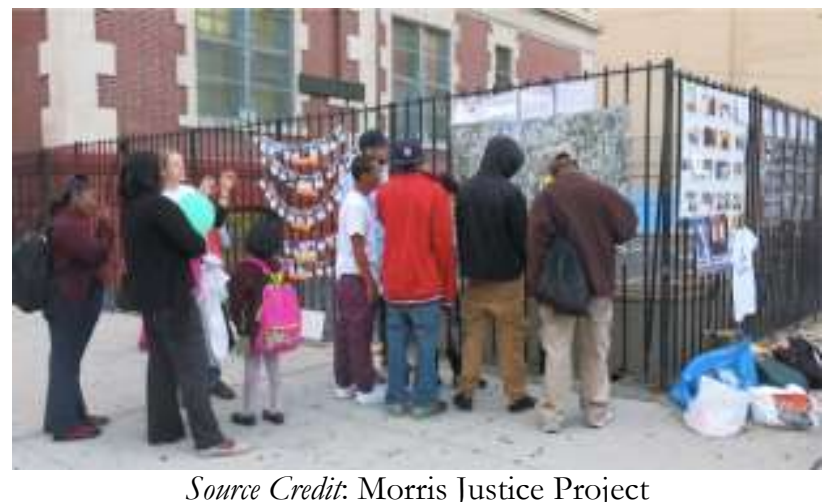

All of these activities were designed to generate public discussion, promote education, and inspire action. "I enjoyed every bit of our sidewalk science - so many people were interested! I think a lot of people learned a lot and I think they carried the work and shared it with others. My technique to get people to stop was to say we have some information on the NYPD if you're interested, and maybe we can get your input on it and if there's anything you'd like changed. Of course I would then tell them a little bit about what I've been through. I think that opened them up even more, once they heard what you've been through or what you've done" (Fawn). "It was great just talking to the little kids and handing out the t-shirts that said on the front, "It's not a crime to be who you are" or "Why do I always fit the description?" and on the back, listed the number of police stops in our neighborhood that year" (Jackie). "It was fun for people who stopped because we were asking them to take a picture. We had t-shirts and we were giving out things, so it was a little easier than when we were asking them to fill out the surveys. The first day we did it we weren't sure if we were allowed to tie things to fences, or even if we were allowed to chalk things on the sidewalk. We also wondered if it would attract people but people stopped, and they took pictures and it worked" (Prakriti). "It was incredible to see the power that the data had for generating conversations among people living right next to each other but who didn't really know each other. People would point to their blocks and compare numbers and would debate why police focused on some corners and not 
others. It was not uncommon for people to spend time with us, leave, and then come back 10 minutes later with friends and family in tow. It was a chance to see and re-see, to name patterns, and to have your individual experiences validated and contextualized in a much broader, collective context" (María). "For me, my favorite moments about sidewalk science were the opportunities to talk with people who disagreed with our findings and interpretations - the counter stories, the people who took the other side from my own. I remember talking with a man who identified as an African immigrant. He described some of the cultural tensions in the neighborhood, some of what he called the 'rowdiness' and the need for police. He respectfully examined our sidewalk science stations but took issue with our interpretations. We had a great discussion about the neighborhood, about police, about schools, about politics, about cultural differences - we shook hands at the end. I loved it" (Brett).

Sidewalk science as emergent action. Over time our research encouraged us to expand our questions beyond police practices. We heard from our community conversations that community safety was about the desire to live life with security and integrity, it was about housing and gentrification, it was about jobs, recreation, and opportunities, it was about education and public health. The expansion of our research was tracked in our sidewalk science. In the first summer after we finished our pocket report we focused on stop-and-frisk, which at nearly 700,000 stops the previous year was a burning issue for poor communities of color and the reason the Morris Justice Project began. As we learned more, our sidewalk science sessions expanded to explore with the community the larger issue of "Broken Windows" policing, and we spent more time focusing on "community safety." And as our work continued, we began to think with neighbors about what healthy communities might look like with less police, we thought about school resources and discipline, we unpacked neighborhood housing policy and future neighborhood development. In other words, we began to explore the circuits of dispossession connected to neoliberalism (Fine \& Ruglis, 2009; Harvey, 2007), strategies for resistance, and sustainable solutions.

Our sidewalk science activities were reimagined to meet the shifts in our research and the evolution of policing in the City. In 2014, Bill de Blasio was elected Mayor on a reform stop-andfrisk platform. He in turn appointed William Bratton Commissioner of the NYPD. Bratton is widely known as "the father" of Broken Windows policing and the person who introduced the practice to NYC in the 1990s during his first time as commissioner of the NYPD (Camp \& Heatherton, 2016). The new administration shifted the narrative around policing in the City replacing commonly known "stop-and-frisk" with less familiar "Broken Windows." Soon thereafter the number of recorded police stops fell drastically. The drop, while widely publicized, did not resonate with experiences of policing by residents in poor communities or communities of color. All of these changes presented an important opportunity for sidewalk science.

Working with the artist Evan Bissell, who joined the Morris Justice Project for two summers to deepen his learning about PAR, we created a series of large posters that explained and questioned the philosophy of Broken Windows. The posters featured portraits of Morris Justice researchers with "We are Not a Broken Window" emblazoned across the bottom, and underneath, a collectively written paragraph defining Broken Windows, connecting it to stop-and-frisk, challenging its effectiveness, and clarifying the real material needs of the neighborhood (jobs, affordable housing, quality schools, etc.). We wheat-pasted near "life size" versions of the poster all over the neighborhood. We distributed smaller sized posters to local businesses, and we taped the smaller version on doorways, lampposts, fences, and any other surface we could access. By placing ourselves in the poster, we hoped to personalize the action, grounding it in the neighborhood, and continuing to invite community conversation. "I've lived up and down these 42 blocks. I know people. My kids grew up here. My cousin's kids grew up here. It meant a lot to communicate this way. It stood for 
something rooted in our neighborhood. Some people put up the posters in their stores and windows. And then my kid was like, 'Ma, someone said they seen you up on the door"' (Jackie). "I was at the doctor and the nurse said, 'I know you, I saw you, I saw your huge image on the wall while walking to work"' (Nadine). "Yeah, my friend called me up and said, 'you famous. I seen you on a door inside my building!"” (Fawn).

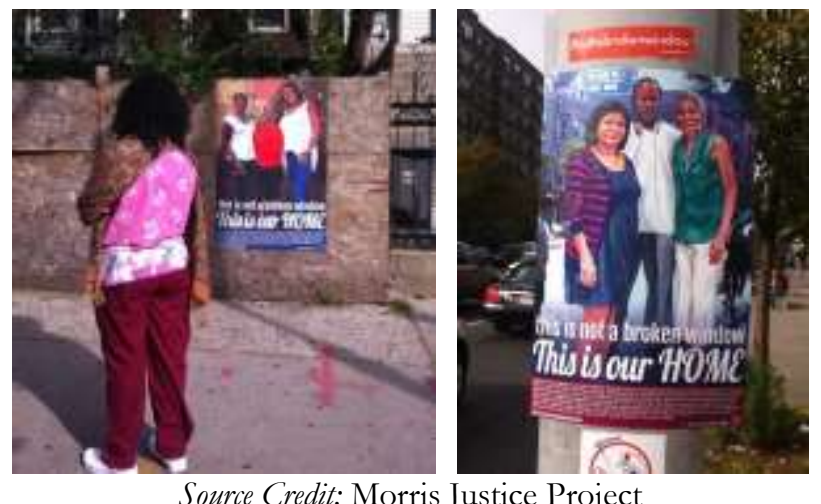

Sidewalk science as action challenging privilege. As our sidewalk science expanded, so did our understanding of possible audiences. Yankees Stadium held a complicated and contested presence throughout our research, though we never directly engaged it during the first few years of the project. It was a tourist destination largely used by people from outside of the South Bronx who could afford to spend hundreds of dollars on baseball tickets, craft beer, and gourmet food. Our data suggested that residents understood the increased police presence during game days as a strategy to "protect" Yankee fans from the "ghetto" just outside the stadium walls. The Morris Justice Project decided to design a sidewalk science session to deliver an open letter from our data to the thousands of Yankees fans who flood the neighborhood on game days. We created "Dear Baseball Fan," a card that we handed out to over 2,000 people entering the stadium over two games - representing the number of neighbors we had engaged with our survey and various methods. The front of the card had what looked like an official Yankees logo but closer inspection revealed that the Uncle Sam hat was replaced by a police hat and the "Yankees" lettering was replaced by "Broken Windows." "We wanted people to think they were getting something Yankees related as they were walking to the stadium. It was Derek Jeter's last home games, so people were eager to have collector's items" (Brett). Inside the card was a collectively written letter that confronted and reframed the false assumptions of the neighborhood held by many fans, assumptions that mirrored the City's justification of its use of Broken Windows policing in communities of color.

Our writing attempted to redirect the racist causal narrative that positioned South Bronx residents as "the problem" with a narrative that, instead, re-places neighborhood problems with problematic discriminatory policies that, for example, concentrate investments in aggressive policing and surveillance rather than policies that create the material conditions for flourishing. "The Yankee Stadium thing. I just have funny memories. The fans were excited to get the letter at first. And then a few of them - like when I started to explain what it is we were doing - they were kind of like, 'Oh. I thought it was something else.' Like the look on their face - we interrupted their steady walk into the stadium - but for the most part they let me finish my pitch, and they didn't toss them" (Anthony). And that was exactly the point. We attempted a critical interruption to awaken a "sense of injustice" (Deutsch \& Steil, 1998; Stoudt, Fox \& Fine, 2011) as they entered the stadium. "We walked around the stadium to pick up any letters thrown on the ground and surprisingly, hardly any 
were. And my friend who works in the stadium said she saw people reading them. After the game she only found one on the ground, and it had $\$ 200$ in it!” (Fawn).

Sidewalk science as action from the neighborhood. What makes sidewalk science unique is the way it connects to grassroots research and organizing. "Sidewalk science is grounded in data. Our activities, our purpose is to produce a collective discussion through the aggregated voices collected in our data" (María). Our sidewalk science activities/products were purposely data-driven for use within the South Bronx and beyond. For example, we produced "Public Science Shorts" - a series of small videos featuring our most important findings that could be easily shared through social media. We created an online presence through twitter, tumblr, and a daily courtroom blog during the Floyd trial, one of the three federal lawsuits claiming racial discrimination in the NYPD's use of stop-and-frisk. The virtual forms of sidewalk science amplified our findings from the sidewalks of the South Bronx across the city and expressed support, solidarity, and the usefulness of community data to/for/with the police reform movement. It helped us establish strong and reciprocal relationships with a host of citywide activities, including grassroots activism, legislation, and lawsuits. By connecting to the larger movement we were able to act locally and citywide, expanding our networks, relationships, accountability structures, contributions, and ultimately, our impact.

During the first several years of our project, the police reform movement in NYC organized itself, grew, and ultimately became very powerful citywide. Its marque initiatives at the time included several class action lawsuits, a set of bills proposed in the NY City Council, and a focus on making the NYC mayoral campaign about a referendum on the policing tactics of the previous administration. Significantly, Jackie and Fawn became co-plaintiffs in Ligon, et al. v. City of New York, et al., one of the high profile class action lawsuits regarding the NYPD's "Operation Clean Halls" program (their case was recently cited by Supreme Court Justice Sotomayor in her Utah v. Strieff dissent on expanding police rights to search.). In combination with another high profile class action lawsuit (Floyd et al. v. City of New York, et al.), rallying at the courtroom with many other groups became an important demonstration of solidarity for us. "When we went to the court, that was the first time I actually sat in a real courtroom. And I gave a public speech outside the courthouse. I'm not a public speaker. It was scary. But when the crowd chimed in or yelled out as I was speaking our data - like call and response - I thought wow people really care" (Prakriti).

With Morris Justice Project signs, buttons, t-shirts, posters, and flyers, many of us sat in on the trials, attended important City Council votes, and represented the project at City Hall rallies and press conferences. We spoke about the findings at local town halls, block parties, and through various media outlets (e.g. journalists, documentary shorts, television). These events provided opportunities to speak with mayoral candidates, City Council members, and other local politicians. One City Council member - the co-sponsor of the police reform legislation - grabbed our sign with the quote, "It's not a crime to be who you are" (a quote grounded in our neighborhood conversations) at a rally and then continued to incorporate it in subsequent speeches. He blogged about the Morris Justice Project and later wrote to thank us after the legislation passed. Our participation in actions continued as demonstrations and protests grew in response to the murders of Eric Garner, Akai Gurley, Michael Brown, Freddie Gray, and too many others.

\section{Reframing the Community-University Borderlands: The Structures We Navigate to Conduct Collaborative Research Partnerships}

Community-university research partnerships stretch the borders of the university. At worst, this extends or colludes with postcolonial/imperial logics. At best, it moves forward liberatory 
activities that seek to educate for social justice and radically change neoliberal structures. In this section we reflect on what it means to bridge the university, specifically the City University of New York, with the Morris Justice neighborhood in ways that can offer decolonizing and radically transformative research possibilities. We ask what personal, community, and university negotiations are needed as groundwork to create and sustain community-university research partnerships that resist the reproduction of violence against marginalized communities? What are the ways that participatory action research, like the Morris Justice Project, can be understood as a university intervention rather than the more typical though unfortunate framing of community intervention? This section begins by exploring the ways we navigated the "community university" and ends by discussing how we pried open uncommon university spaces.

\section{Navigating the "Community University"}

One of the gifts of the Morris Justice Project was the necessity to conduct nearly every aspect of the research in "the community" - in the neighborhood itself. Bringing the university to the community was not without challenges. "In many ways it's is easier to do research at the university. We have office space, we have supplies, we have technologies all right there. But research like Morris Justice can't happen in our offices - we need to transport everything to the South Bronx. Many of the activities for the meeting need to be prepared beforehand - often with a smaller group of the larger collective. Printouts, data transcripts, statistical output plus the speakers, computer, projector, we even have a printer and button-maker - all need to be portable and brought with us. Though it shouldn't be mistaken for a redistribution, we're really taking the university and some of its resources to the South Bronx" (Brett). Reimagining and reshaping the site for the production of public science through participatory action research is an investment that takes into account a host of considerations. In this section we address the negotiations that needed to take place in our respective communities - in the South Bronx and at the university - in order to build what might (perhaps too generously) be called a "community university." For the Morris Justice Project, there were four prominent areas that required concentrated negotiation: home, community space, neighborbood surveillance, and university accountability structures.

Negotiating home. In order for our community-university partnership to begin and flourish, everyone involved had to negotiate an ongoing set of expectations, values, limits, and possibilities in their home environments. In our complicated lives, one major challenge involved negotiating a sense of competing work/family responsibilities from "making sure my husband and boys are fed" (Jackie) to "running errands for my grandmother" (Anthony) to "having to work late on the weekdays" (Paul) to "making sure I see my son before he goes to bed" (María). There were competing hospital stays, court dates, and commuting distances. The time, energy, and even financial commitment to the Morris Justice Project were often significant to us personally and to our families, and they sometimes put a strain on our jobs. Participating in research-activism requires sacrifices and sometimes, for some of us, a keen awareness of negotiating neighborhood risks. "I just need to stay on the straight and narrow. I know there are certain areas not to be in so I don't have to come across the police. It's basically, you know, doing what I have to do to stay out of trouble. In turn that helps me to be able to meet up with you all - and you know, get to work. I just got a keep my cool" (Anthony).

Not all of our families understood why we were spending so much time with the research collective. "My mom doesn't understand why I'm involved in this project. She doesn't see my purpose in this - I'm not a black male. She doesn't like when we have evening meetings and I have to walk home alone at night. I'm a first generation immigrant who moved from Bangladesh to the South Bronx when I was very little. I'm not married, I don't want to get married yet, maybe ever, but 
my parents, rooted in tradition, tried to make arrangements over the years" (Prakriti). And while everyone involved with the Morris Justice Project has stories of personal hardships and family sacrifice that they had to negotiate in order to continue their participation, the deep sense of purpose kept each of us returning. "Anything worthwhile is worth working for, waiting for, and doing whatever is necessary to get it. You've got to fight for a lot of things you want and need. Somebody's got to do it, right?" (Jackie).

Negotiating community space. Negotiating space was an ongoing challenge for the Morris Justice Project. At first we were able to build a relationship with a librarian who allowed us to use space in the local library ${ }^{2}$. After she left, her predecessor felt we were "too political" and it became more difficult to use the coveted basement community room. "I truly don't think our project would have gotten off the ground without having the library basement as our primary meeting room" (Brett). "There is just no inside public space to have a conversation. You can't have a community conversation unless you are standing on the corner. And if you are standing on the corner, then you'll get pulled over by the police!" (Cory). "Sometimes this local organization that we've established a relationship with lets us reserve rooms but it requires them to open the locked door for us and then find someone willing to stay after hours until we leave. That's a lot for them. More typically, we have to use the backroom of a bar over by the stadium - but the music is loud and during game days can be crowded. But we've made the best of it - Yankees Tavern has our orders memorized!" (María). "Why do they encourage the bullshit and shoot down the positive why aren't there places for us to spend time positively in our own community?" (Anthony). Our struggle for space was reflected repeatedly across our data and directly connected to the very purpose of our project.

Whether claiming "public space" in a restaurant or local bar, or the courtyard of the imposing Bronx Criminal Courthouse (before it was fenced off), we often found ourselves "taking" space for our own purposes without notice. We have to negotiate the risk of doing this every time for each other and for others outside our group. For example, before our unannounced "Illuminator" event, Jackie alerted neighbors that used the area. "I knew because of our action the police might come out - and I was right, they did - and you know, different people would be attending, like white folks from outside the neighborhood. So I didn't want nobody to feel like they were going to get busted or anything like that. And if that happened I didn't want it considered OUR fault, being that we live in the area. So I just went on and gave them a heads up. Because these are people I see every day" (Jackie). Jackie's contextual expertise assured the continued survival and effectiveness of our work, as well elevating our ethical practice.

Negotiating neighborhood surveillance. Negotiating the fear of surveillance for associating with the Morris Justice Project emerged as another major challenge for the continuation of our community-based research. At the beginning of the project there were many young men from the neighborhood who played a vital role in deciding the overall design of the project as well in developing our survey and interview protocols. However, as time went on, some became increasingly concerned about how their association with the research would position them in relationship to their peers. For example, several of the young men did not want to meet in a church space just south of the neighborhood after we lost our space in the library. "Some of them just didn't feel safe meeting down there. They're from this part of the neighborhood. It wouldn't be good for them to be seen down there" (Fawn). "Being young and in these areas, you know, certain areas you just don't go in. Some kids, because they don't have anything, they get serious about their

${ }^{2}$ We are grateful to Dawn Holloway, the local Library Manager who believed in running a public library for and with the local community. She supported our research with space, time, assistance, and expertise. 
territory. So you're not just going to walk in there without them knowing what you're there for. And then if you walk in there with a bunch of white people, and then later the police come, the first thing people will say is 'they set em up - a snitch.' It just gets out of hand" (Nadine). "People jump to conclusions very quickly without finding out what's going on. The kids don't want that extra pressure" (Anthony). The very real consequences of being watched caused a threat that, at times, impeded Morris Justice members from participating. "It can turn violent. I remember that one time we were having a Morris Justice meeting in the library. We took a break and I was smoking outside. My son and his friends from the meeting were taking a break with me. And from the other side of the street a group of guys came running towards us and flashed their gun. I screamed and closed the library door" (Fawn).

When it came time to distribute the survey, most of the young men felt it was too risky to participate. It simply felt too uncomfortable to walk around the neighborhood and ask questions about policing. "Our young men were constantly being stopped, the police coming into their building complexes and courtyards - so they didn't even feel safe at home. The police were harassing them, picking on them, knowing their names personally. It got to the point in our project for them that being so out there in public, walking here and there and talking to people - it just felt like too much. The police already know who they were and now they're asking questions about the police department? So a lot of them said no, they were going through enough already" (Jackie). "The police knew our kids by name. They knew me by name. 'Hi Miss Bracy,' they would say. You don't know me like that. They were trying to intimidate us - like I know who you are and what you're doing. The boys in the group worried that the police would specifically target them if they knew they were involved in a group criticizing policing" (Fawn). "They didn't want their pictures taken. They didn't want their image filmed. They didn't want their names attached to the project. There was just so much to risk for them" (Nadine).

As community resistance to stop-and-frisk escalated and police responses intensified, it continued to feel too unsafe for young men to join or rejoin the research. "I have tried to bring my son around to the Morris Justice Project on several different occasions. He's a little nervous. He thinks he might be coming home from school and because the police recognize him for participating, they might retaliate for him being a part of this. So he's a little nervous being the one to step up. I don't want to force him to do anything. As long as he has me, he can voice his opinions and I will always bring them to the table - and maybe one day he'll get involved" (Paul). The absence of the young men was filled with care by adults in the group - mothers and fathers with teenage children - who stayed involved on their behalf. "I'm an adult. I don't care if the police target me. I stayed in for them. I represented them" (Fawn). "I stuck around not only on their behalf, on my behalf and on their behalf. I had to represent them, we had to represent them. Some of them have parents that unfortunately just don't give a damn. So you have to stay and represent everybody, not only representing mines I am trying to represent the next one too - so it will be a lot better for all of us" (Jackie). The Morris Justice Project was able to continue infusing the expert knowledge of young people in a way that was safe and responsible through the advocacy of adults.

Negotiating the university accountability structures. Community-university research like the Morris Justice Project, required "prep work" and sacrifice within the environments we each lived. We all needed to negotiate structures on behalf of the project, to maintain it, and to prevent it from hurting, misrepresenting, or exploiting marginalized communities. This happened in the community but it also happened in the university. One of the primary structures that Brett, María and their students needed to negotiate - the environment that they most often contended with was the university. 
Brett and María approached this partnership committed to "public science," a praxis of community-engaged scholarship for social justice. However, being a publicly oriented scholar or identifying as a scholar-activist is often discouraged and deemed inappropriate for "professional" university researchers - particularly pre-tenure. The priorities of the university incentivize a limited strand of research. To conduct long-term, collaborative, community engaged research for the explicit purposes of documenting oppressive policies and promoting social justice, is generally pursued despite, not because of, the norms and expectations of the university. Moreover, if pursued, it is done within the limits and contortions required for tenure, promotion, and the overall standards of achievement in academia (Fine, 2007). It is seldom good for academic advancement and generally relegated to the margins of most social science disciplines. "The work we pursued was slow, longitudinal, not funded with large government grants. It was truly collaborative which meant it went in directions we had not anticipated and wasn't necessarily conducive to what the university required of me. We knew we would not and could not publish quickly and, besides, publishing for an academic audience was not our first priority. The methods we used were not standardized, experimental, or always quantitative. We did not claim objectivity. We took a stand to advocate for social justice. This is not a recipe for huge university accolades and that's certainly okay. However, María and I are still both university professors with a large amount of teaching and mentoring commitments. Our paychecks and promotions exist within the current neoliberal logic that has a strong hold within higher education in the United States. As a result, doing this type of research is something not always easily managed within the written and unwritten expectations of university employment and within our academic disciplines. María and I, along with all the students who joined us throughout the years, have been extremely fortunate to work within the protective umbrella of the Public Science Project" (Brett).

The Morris Justice Project is situated inside an ongoing university based intervention known as the Public Science Project. This particular intervention is a research collective of scholars officially established in 2008 at the Graduate Center of the City University of New York and designed to cultivate, teach, innovate, and in general advance public scholarship rooted in the values and practices of critical participatory action research. The mission of the Public Science Project is to be a safe professional shelter within an increasingly neoliberalized university mired with shrinking budgets, centralized control, increased scrutiny, and greater expectations. It attempts to pry open, keep lifted, and push forward university spaces for "scholar activists" to do high quality research about socially relevant topics that can help assist/create change. It attempts to serve as an ethically accountable bridge for university-community partnerships designed to advocate for fairer, more tolerable human conditions. At times, like with the Morris Justice Project, it has even served to financially support this work when other granting agencies were unwilling.

University-community partnerships are potential sites of violence even for the most wellintentioned academics. Resistance to structural violence of university research requires coalitions of scholars to reform from within their professional homes and build solidarities across academic networks (see urbanresearchnetwork.org). This also requires that participatory researchers inside the university find ways to navigate around (not collude with) the narrowly defined versions of scholarship, knowledge, or expertise. Brett, María, and their students were able to more freely navigate the confines of academia because of the resources, opportunities, and legitimacy provided by the Public Science Project. In this way, the Morris Justice Project emerged out of and has been sustained by the spaces pried open from this important, ongoing university-based intervention.

\section{Prying Open Uncommon University Spaces}


Good participatory research interferes with university status quo. South Bronx community members invited university professors and students into their neighborhood - their home - in order to construct a locally oriented research-activist partnership. In this way, the Morris Justice Project was designed to engage community-based research and action towards police reform. Police reform was the primary ambition and our project helped contribute to personal, community, and institutional change. However, with the help of the Public Science Project, university professors and students also invited South Bronx community members into their academic "home" and by doing so the Morris Justice Project served as an intervention of university spaces that are traditionally exclusionary. ${ }^{3}$ After the first few years of our project, we sought to communicate with/to university audiences through traditional academic activities such as publishing, presenting, and educating. By doing this, we often found it challenging to convince the academy (and other institutions of power) that we were an authentic collective who co-constructed knowledge, that we had valuable expertise to teach, and that we had important scholarship to contribute. In this section we illustrate these challenges in more detail.

Yes, we co-constructed knowledge. As a collective, the Morris Justice Project had serious concerns about how the central values and normalized incentives of universities shape narrow research practices in ways that can promote structural violence against communities of color and other marginalized communities. Our counter response to that concern was the pursuit of public oriented science through participatory action research. We believe in the value of broad expertise, collaborative inquiry, democratic spaces, and the explicit joining of scholarship with activism. This is uncommonly practiced in the academy where intellectual contributions are more typically to emerge from individuals or small groups of individuals firmly rooted inside the university. University collaborations with partners outside the academy, like with independent community organizations or individuals, do not easily fit within the well-worn structures of the academy. For example, university ethical review boards overseeing research are not designed for the production of knowledge through "community" involvement (who are the "subjects?") and grassroots activism (is this even research?). Ironically, these mandated institutionalized "ethics" make it more difficult (if not impossible) to conduct ethical research with (not on) communities.

The widely held notion that valid/ethical knowledge production is essentially an individual academic activity, rather than one that is inherently social and collective amongst many people in and potentially outside the university, has presented challenges for the Morris Justice Project. We are frequently forced to resist misinterpretations of our work that privileges the status of the involved academics while rendering those outside of the academy as invisible, irrelevant, assistants, or in need of assistance. For example, The Monitor, a professional magazine published by America Psychological Association (APA), did a feature article on the Morris Justice Project. While honored, we worried the "story" would twist Brett and María into a privileged trope: noble academics, venturing out to the wilds of the South Bronx to save a poor community of color. It is too inaccurate and uncomplicated to represent us this way. We insisted the journalist speak with and include in the article as many members of the Morris Justice collective as possible and to frame us all as "coresearchers." With short notice, the magazine sent a professional photographer to photograph only Brett and María in the South Bronx. We resisted and invited the group, but given the timing only Jackie was able join. And though many photographs of the three of us were taken that day, the final magazine proof left Jackie out.

\footnotetext{
${ }^{3}$ While we have, as a collective, invited each other into our actual homes, we are not here intending to create a false equivalency between "neighborhood home" and "university home." The differences in vulnerability, power, and intimacy are not the same between these spaces.
} 
Again, we resisted. We explained to the magazine that our approach strives to resist harmful research practices and representations. Too often, privileged academics have spoken about entering "communities of color" as if they were places in need of rescuing or intervention, rather than acknowledging, as in our case, collective outrage, shared fates, individual passions, and a deep sense of mutual implication. We have tried to instill this ethic with all those who have asked to work with us - whether journalists, lawyers, artists, or documentarians - by insisting they create strategies to enter our participatory space as partners. It is not always easy nor always fully possible, but it is the only way we can maintain the integrity of our collaboration. With The Monitor we were able to get the magazine photo changed (see photo below). It was a small win for community-based research. We were less successful at resisting patriarchy - the white male positioned in front of two women, windblown, "heroically" gazing at the sky.

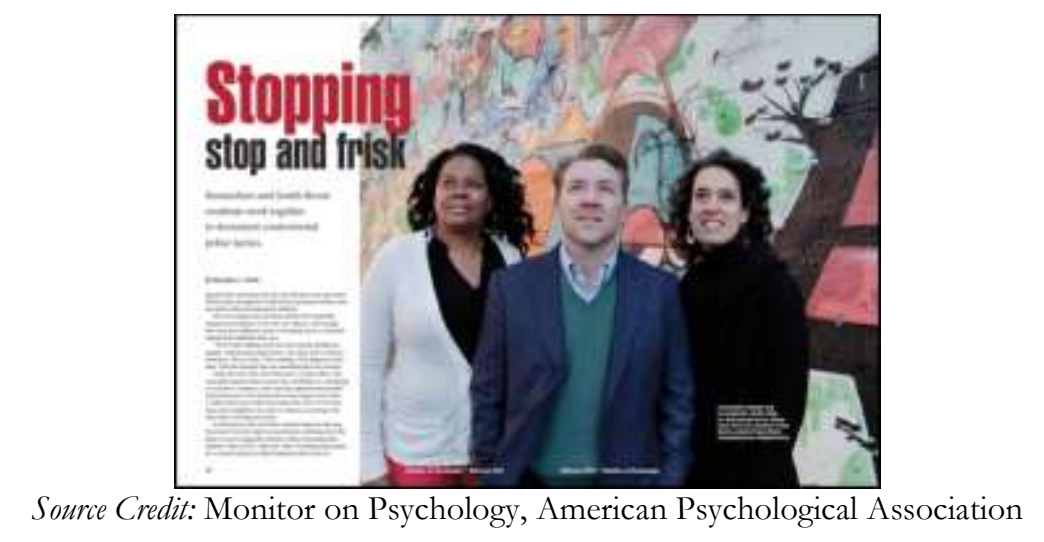

What we often encounter is not malicious nor necessarily intentional exclusion but, rather, people operating within a limited and normalized (elitist) academic structure. People are generally unexposed to the values that participatory action researchers practice. Our most effective interventions, then, are vigilance, counter-hegemonic education, and persistence. We work for "small wins" - prying open and expanding small spaces to push forward the values of "scholar activists." For the Morris Justice Project, we wanted to be understood as a collective. We wanted other academics to understand that we co-constructed knowledge together and that our research was not an individual "sport." But the idea of a community-university research collective does not easily fit within academic standards.

We have expertise to teach. The Morris Justice Project challenged the ever-narrowing definitions of legitimate science as only conversations directed at other academics. Instead, we wished to promote the legitimacy of alternative types of scholarship. What do peer-reviewed conference presentations or journal articles mean for community-based researchers whose primary purpose is to engage in critical dialogue with other community members and a citywide police reform movement? After all, whose peers are reviewing? Once we decided to more directly disseminate our work to academic audiences through writing and presentations, we had to negotiate ways to do that collaboratively. Traveling as a collective is difficult and often costly. Preparing for a presentation or organizing everyone's ideas into an article is difficult. Everything takes longer and is a bit more complicated. It requires a commitment to each other, the research, and the goals of coconstructed knowledge. We find ourselves better and more effective as a team. "It was meaningful to talk about the project for our article. It was really another stage of analysis" (Einat). Indeed, we learned that presenting and publishing have offered us new reflexive spaces for critical interpretation of our data and our research process. We have also made mistakes along the way. We came to realize 
that our early presentations were divided unequally in ways that reproduced the supremacy of the university. The academics were tasked with explaining the technical parts of the research and the community members were tasked with describing their experience with police and the research process. We unwittingly enforced these roles on each other, as did our audiences. We now more consciously divide our talks in more complicated, less stereotypical ways.

On multiple occasions the Morris Justice Project has been invited to conduct workshops or give classroom/conference presentations with the explicit purpose of educating academic audiences about the process of doing participatory action research. What makes us unusual as scholars is that we are speaking with/from a deep, grounded, and long-term commitment to a 42 block neighborhood in the South Bronx. It is to this neighborhood, rather than to other professors or the university, that we hold our academic work primarily accountable. "Each and every time I speak about our project at a presentation, I believe that I'm giving the concerns of my neighborhood voice" (Paul). So the opportunity to teach academics about our work was particularly meaningful for us and, we think it is particularly worthwhile for the academic community to learn from the expertise of the South Bronx. "To find out that these colleges and professors were so interested in the way we went about doing our research and how they could do their own - making sure the community gets involved and catching the eyes of the police and politicians and all - it's just amazing. It was great to talk to these very fancy audiences, be an example, maybe to help them see things differently" (Jackie). "It's been uplifting for me because it was like wow - for me to be feeling like just some guy from the block to now doing presentations and getting all this positive feedback from like-mind individuals, you know, it's like a good feeling. And when we first started presenting, my whole state of mind, I was a nervous wreck. But then the reception we got - I remember this one moment a person in the audience was so moved by what I said she handed me a letter afterwards telling me to 'keep going, continue what I was doing.' It was really emotional. I keep that letter in a very special place" (Anthony).

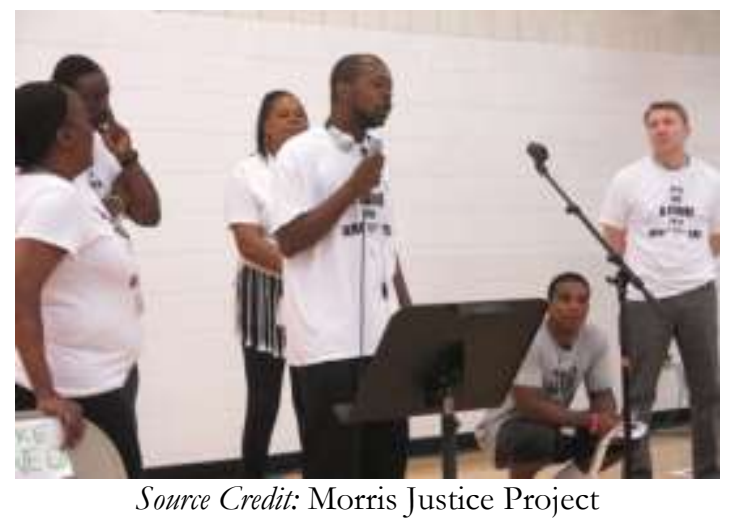

While the reception we have gotten has often been quite positive, academic spaces can be hostile to those assumed nonmembers. This presents a considerable impediment to the full participation of community researchers. For example, the Morris Justice Project was honored with an invitation to give a Presidential Address for Division 45 (Society for the Psychological Study of Culture, Ethnicity and Race) at the American Psychological Association's (APA) annual conference. We often wear our Morris Justice t-shirts when presenting, the same ones we wear during our sidewalk science sessions. After the address we gathered outside, proudly taking pictures, celebrating our success, when a conference security guard stopped us and questioned if we belonged. Commenting on our shirts, the guard asked if we were protesting and told us to move to the 
designated protest area. It deflated and then outraged us. We shared what happened with colleagues and, to the credit of many, we received an apology from the Chief Executive Officer of APA, Norman Anderson, who wrote, "I am writing to express my deepest and sincerest apology for the incident of racism and micro-aggression that occurred... needless to say, I was appalled.... This type of treatment of our attendees (or anyone) is totally unacceptable, is contrary to the core values of APA, and is disappointing and embarrassing to me personally." We also spoke with the events manager and head of security of the convention center where the conference took place. While the events manager apologized, the head of security, though apologetic, was ultimately unwilling to issue a formal apology and, more troublesome for future conferences, was unwilling to connect this incident to race.

Though the struggle continues, this experience helped elevate collaborative communitybased research within mainstream psychology. Norman Anderson ended his letter by saying, "One positive result of this negative experience is that I got to learn much more about your very innovative work with the Morris Justice Project. This type of creative participatory action research is desperately needed across our country, now more than ever, and shows how communities can use scientific methods to bring injustices to light in ways that are not easily dismissed as subjective or anecdotal. I believe psychologists need to have greater exposure to this type of research." In the end, it was a small but meaningful intervention into the academic machine that was brought about by a collective of academics who stood up on our behalf to carve new spaces for community researchers.

We have scholarship to contribute. Knowledge produced outside the academy that is generated on the streets from experts without degrees (by citizen or street scientists), or that emerges from and through the direct impact of structural disadvantages, is often understood (if acknowledged at all) as unsystematic, subjective, parochial, and politically biased. The insistence to take the Morris Justice Project seriously is an insistence to take our process and our findings seriously.

In many ways, our participatory process has been well received, even if, we suspect, as an exotic or novel practice. However, more difficult has been finding spaces to speak as experts on policing, or in other words, experts on content rather than process. We produced valuable scholarship that went beyond the novelty of our research design. So when we were invited to speak at the White House Forum on Citizen Science, we also wanted an opportunity to speak about our findings. As honored as we were to be invited, we asked the forum coordinators for more: we asked to be taken seriously as scholars with important data to share. They responded by organizing a meeting with Roy Austin Jr., deputy assistant to President Obama and director of the White House Office of Urban Affairs, Justice, and Opportunity as well as other White House staff.

On two other occasions our work has wrestled with receptions that vacillate between important recognition of collaborative research and claims of bias or advocacy rather than social science. In Toronto and in New York City our research caught the eye of lawyers, a few politicians, and community groups as a strategy to "hear from the people" about aggressive policing and how it might be changed. In Toronto, after some consultation with us, a community-led project was conducted and then immediately criticized as subjective and invalid advocacy by Toronto's police chief. Similarly, in New York, the Morris Justice Project was offered as an example of how the Joint Remedial Process (JRP) that resulted from the wins of three major police reform class action lawsuits against the City of New York (Floyd et al., Ligon et al., and Davis et al.), might systematically incorporate the police reform demands of affected communities (as was ordered by the judge of all three cases; see http://nypdmonitor.org/overview/; http://nypdmonitor.org/joint-remedialprocess/). Representatives of the Morris Justice Project met with members of the NYPD, the courtappointed Monitor, and the JRP Facilitator over a period of four months but ultimately our approach was considered advocacy not science. Though not without substantial struggle, some 
elements of the research proposal we helped design ultimately continued on without us and later, as part of the JRP process, we worked with the Facilitator to co-sponsor a South Bronx Town Hall to lift up grassroots community solutions on police reform.

Jackie was ultimately appointed as one of only fifteen JRP advisory committee members, tasked to assist with all of the court appointed reforms to stop-and-frisk in NYC. "The Morris Justice Project and being a plaintiff in Ligon had a lot to do with me sitting on this advisory board. I gave the Judge our back pocket report, our articles, and all of our material. I explained to him that you need people going through the situation to help solve the situation. If you're not living it, how are you gonna to fix it? I know he read all of it. And it's not just me standing up there, telling him what I'm going through. I've got evidence from the whole 42 blocks. We'll see how this advisory group goes" (Jackie). While cautiously optimistic, we remained suspicious of working "inside" the very systems we are fighting to fundamentally change. These points of contact for us have often felt tokenistic at best and exploitive, even violent, at worst. When given access to these "official" avenues for making change, members of the Morris Justice collective have frequently expressed feeling unheard, devalued, misunderstood, and used. In the end, the advisory group fell far short of meaningful community participation. Still, we fight, seeking small wins, intentionally working to resist at multiple levels and in various spaces.

The reality of collaborative community-university research is a struggle against status quo - a constant push against the standards and structures of mainstream policy change or mainstream social science. Our wins are often only partial but they create cracks. For the Morris Justice Project, collaborating to produce journal articles and presenting in university settings or having policymakers take seriously our expertise as scholars are forms of action, like sidewalk science, that open spaces for critical conversation through our research. We are pushing against the narrow walls of the academy, reshaping the limited outside representations of what reputable academic research looks like, to intervene against the structurally violent historical legacy of university research in poor communities and communities of color.

\section{Conclusion: The Morris Justice Project is Public Science}

Large numbers of people across cities, campuses, and coalitions are taking action and challenging the ongoing pervasiveness of state sanctioned police violence and the unprecedented expansion of the carceral state enacted largely on poor black and brown bodies as well as other people whose often intersecting positions are relegated to the margins, considered a threat, and targeted (e.g. LGBTQ-identified, homeless or precariously housed, immigrants particularly undocumented, people with psychiatric disabilities and mental health issues, Muslim practicing religious groups, and activists, among others). This represents a national and even international movement emerging from the ongoing conditions of structural violence that intimately threatens and criminalizes the lives of poor communities, especially those of color, not only on the streets but also in their homes, at their schools, and in their workplaces.

People across the country - like members of the Morris Justice Project - feel a sense of urgency to stop these everyday, enduring collisions with police surveillance, control, and discipline. They are standing on the shoulders of generations past to continue the struggle, resolved to make radical change. The movement is organized and widely connected but its power is generated from the energies of countless organically produced actions; this activism ranges from people on the ground in Cop Watch patrols to civil disobedience to flooding the streets in protest to becoming plaintiffs in class action lawsuits. People are angry, the numbers are growing, and they are unwilling to let these oppressive conditions stay the same. The Morris Justice Project represents a seldom-considered but 
important form of grassroots activism in solidarity with reform and radical change movements: participatory action research.

Community based research is complicated and messy and longitudinal. We write this conclusion with a sense of humility and uncertainty as well as a sense of pride and accomplishment. The commitment the Morris Justice Project collective made to each other was to systematically collect important information about policing in the community that could, throughout the process, provide moments of collective knowledge building, facilitate awareness, spark conversation and, if the data warranted, seek opportunities for advocacy and activism. Our pursuit of changes in the way the NYPD policed the neighborhood led us towards an ongoing set of activities, strategies, and alliances that helped us speak to/for/with the 42 blocks we studied as well as meaningfully connect with the ongoing police reform movement citywide.

The Morris Justice Project has given us as a collective and as individuals the tools and power to have a seat at the city-wide reform table. Several years ago, Paul said, "I think the statistics that we have gathered speaks for itself, so I believe at some point we might be able to sit at the roundtable and talk with the commissioner." In fact, along with a small group of police reform organizations, the Morris Justice Project was offered a seat at the roundtable with the new commissioner. The group chose Jackie to represent us and she went covered with buttons, wearing our t-shirt, and carrying our back-pocket reports. "Eventually some eyes will open and some changes will take place. We know that with research and time more than likely something will transpire out of it. But we also know it is not going to be instant. It will be slow. We will be able to see it, we will be able to recognize it, but it won't be anything that happens overnight" (Paul). It has taken time, but we see the possibilities of community involvement and community research for us and we see it for others too. "In terms of the people reading this, maybe they can see what we've done and if this is happening where they're at, maybe they can start something that can help their whole community. It doesn't have to be about the NYPD, it can be about something else. People can learn a lot from each other" (Fawn).

Now, in the braiding of strong research, action, and education, we - in our unlikely family have developed a new identity as the Morris Justice Project. It is something that didn't exist for any of us before but is now so important to each of us. We are a family of a different kind. It is something that we feel ownership over and a responsibility for. We have a history, an identity, and a future. And - as fleeting and small as it may be - we have collectively made a difference. We are "not going to tell you, once you fill out our survey, the next day it is going to be all right. It is going to take time. But all it takes is a start. Somebody got to do something because if you don't there is no hope - your eyes still are going to be closed. You can't even crack them open and say, 'well maybe.' You can break a lot of things if a lot of voices get together and start screaming to the top of your lungs, 'we're not going to take it anymore!"' (Jackie).

The Morris Justice Project is an illustration of public science: Publically oriented science by the public, with the public, for the public good. At the end of the talk that Jackie gave at the White House, she admitted, 'We've had influence in ways I never thought possible when this project began. Look where I'm at today. I've shown my sons that change CAN happen. We CAN make a difference. But, our work is not over." She recognized that our project allowed us all to take on new identities, "I am not only a wife and a mother - I am a researcher, an author, a speaker, a community organizer and an activist." And she concluded by (re)claiming her neighborhood, "The Morris Justice Project is about more than policing. It's about creating opportunities for our children and our community. This is OUR home. We live here. We work here. We play here. We shop here. We pray here. We deserve policing with dignity and respect. Public science is an important part in helping us 
advocate for our neighborhood." As she walked from the podium, the audience gave her a standing ovation.

\section{About the Special Issue}

This article is part of a special issue of $\operatorname{EPAA}$, Collaborative Research for Justice and Multi-Issue Movement Building: Challenging Discriminatory Policing, School Closures, and Youth Unemployment that was edited by Ronald David Glass and Mark R. Warren and curated by the Urban Research Based Action Network (URBAN). This special issue reflects the network's commitment to producing and utilizing research for justice that combines rigorous scholarship with the arts to engage both the head and heart so as to deepen and express our social justice values in our scholarship. In addition to the cases highlighted in the title of the special issue, there are also essays that interrogate the limits and possibilities of universities for supporting collaborative research for justice, that explore the role that URBAN has played in fostering the formation of both an academic field as well as experiments in fusing knowledge production with knowledge mobilization and community organizing to build movements for justice, and that argue for multi-modal forms of knowing to build the critical solidarities needed to speak truth to multi-scalar powers at local, national, and global levels. These provocative essays are integrated with graphics that explore themes of how collaborative research for justice is related to advocacy and research rigor, how it must navigate institutional barriers and create institutional supports, and how it can play a powerful role in policy development and change. One graphic on the ethics of collaborative community-based research is also integrated with a video commentary. Additional videos feature scholars and activists sharing key lessons about turning points in their careers, accounts of how they put their research to work for justice, and advice they have for the next generation. Another video features scholar-activists reflecting on their experiences as publicly engaged scholars. Taken together, this special issue provides robust guidance for putting truth seeking to work on behalf of and in partnership with the least advantaged communities.

\section{References}

Alexander, M. (2012). The new Jim Crow: Mass incarceration in the age of colorblindness. New York: The New Press.

Appadurai, A. (2006). The right to research. Globalisation, Societies and Education, 4(2), 167-177.

Byrne, D. (2002). Interpreting quantitative data. Thousand Oaks: Sage.

Cahill, C. (2007). The personal is political: Developing new subjectivities through participatory action research. Gender, Place and Culture, 14(3), 267-292.

Camp, J. T., \& Heatherton, C. (Eds.). (2016). Policing the planet: Why the policing crisis led to Black Lives Matter. London: Verso Books.

Chatterjee, P., \& Maira, S. (2014). The imperial university. Minneapolis: University of Minnesota Press.

Chauhan, P., Fera, A. G., Welsh, M. B., Balazon, E., \& Misshula, E. (2014). Trends in misdemeanor arrest rates in New York. Introduction by Jeremy Travis. New York, New York: John Jay College of Criminal Justice, City University of New York.

Chauhan, P., Welsh, M. B., Fera, A. G., \& Balazon, E. (2015). The summons report: Trends in issuance and dispositions of summonses in New York City, 2003-2013. Introduction by Jeremy Travis. New York, New York: John Jay College of Criminal Justice, City University of New York. 
Clawson, D. (2007). Public sociology: Fifteen eminent sociologists debate politics and the profession in the twenty-first century. Berkeley: University of California Press.

Coates, T. (2013, July 24). The dubious math behind stop and frisk. Atlantic Monthly. https://www.theatlantic.com/national/archive/2013/07/the-dubious-math-behindstop-and-frisk/278065/

Cooke, B. (2001). Participation: The new tyranny? London: Zed Books.

Costanzo, M., Gerrity, E., \& Lykes, M. B. (2007). Psychologists and the use of torture in interrogations. Analyses of Social Issues and Public Policy, 7(1), 7-20.

Cresswell, J. W. (2003). Research design. Qualitative, quantitative, and mixed methods approaches. Los Angeles, CA: Sage.

Deutsch, M., \& Steil, J. M. (1988). Awakening the sense of injustice. Social Justice Research, 2(1), 323.

Drabiak-Syed, K. (2010). Lessons from Havasupai tribe v. Arizona state university board of regents: recognizing group, cultural, and dignity harms as legitimate risks warranting integration into research practice. Journal of Health \& Biomedical Law, 6, 175.

Fabricant, M. C. (2011). War crimes and misdemeanors: Understanding 'zero-tolerance' policing as a form of collective punishment and human rights violation. Drexel Law Review, 3, 373414.

Farmer, P. (1996). On suffering and structural violence: a view from below. Daedalus, 261-283.

Fine, M. (2007). Dear tenure and promotion committee: An epilogue of sorts. In Revolutionizing education: Youth participatory action research. New York: Routledge.

Fine, M., \& Barreras, R. (2001). To be of use. Analyses of Social Issues and Public Policy, 1(1), 175182.

Fine, M., \& Ruglis, J. (2009). Circuits and consequences of dispossession: The racialized realignment of the public sphere for US youth. Transforming Anthropology, 17(1), 20-33.

Freire, P. (2000). Pedagogy of the oppressed. Bloomsbury Publishing.

Geller, A. (2015). The process is still the punishment: Low-level arrests in the Broken Windows Era. Cardozo Law Review, 37, 1025.

Gilmore, R. W. (2007). Golden gulag: Prisons, surplus, crisis, and opposition in globalizing California (Vol. 21). Berkeley: University of California Press.

Harcourt, B. E. (2001). Illusion of order: The false promise of Broken Windows policing. Cambridge, MA: Harvard University Press.

Harding, S. (1992). Rethinking standpoint epistemology: What is "strong objectivity?" The Centennial Review, 36(3), 437-470.

Harvey, D. (2007). A brief history of neoliberalism. New York: Oxford University Press.

Hesse-Biber, S., \& Leavy, P. (2003). Approaches to qualitative research: A reader on theory and practice. New York: Oxford University Press.

Howell, K. B. (2015). The costs of Broken Windows policing: Twenty years and counting. Cardozo Law Review, 37, 1059.

Jones, J. H. (1993). Bad blood. New York: Simon and Schuster.

Jones-Brown, D., Stoudt, B., Johnston, B. \& Moran, K. (2013). Stop, question and frisk policing practices in New York City: A primer ( $2^{\text {nd }}$ ed.). New York, NY: John Jay College Center on Race, Crime and Justice.

Kelling, G. L., \& Bratton, W. J. (2015). Why we need broken windows policing. City Journal. Kelling, G. L., \& Wilson, J. Q. (1982). The police and neighborhood safety: Broken windows. Atlantic Monthly, 127(2). 
Lorde, A. (2003). The master's tools will never dismantle the master's house. Feminist Postcolonial Theory: A Reader, 25, 27.

Mitchell, D. (2003). The right to the city: Social justice and the fight for public space. New York, NY: Guilford Press.

Morrow, R. A., \& Brown, D. D. (1994). Critical theory and methodology (Vol. 3). Thousand Oaks: Sage Publications.

Muhammad, K. G. (2011). The condemnation of blackness. Cambridge, MA: Harvard University Press.

Oparah, J. C. (2014). Challenging complicity: The neoliberal university and the prison-industrial complex. In P. Chatterjee \& S. Maira (Eds.). The imperial university. (pp. 99-121). Minneapolis: University of Minnesota Press.

Patel, L. (2015). Decolonizing educational research: From ownership to answerability. New York: Routledge.

Platt, T., Frappier, J., Gerda, R., Schauffler, R., Trujillo, L., Cooper, L., ... Harring, S. (1982). The iron fist and the velvet glove: An analysis of the US police. San Francisco: Crime and Social Justice Associates.

Rios, V. M. (2011). Punished: Policing the lives of Black and Latino boys. New York: NYU Press.

Sandoval, C. (2000). Methodology of the oppressed (Vol. 18). Minneapolis: University of Minnesota Press.

Schneiderman, E. T., General, N. A., \& Bureau, C. R. (2013). A report on arrests arising from the New York City Police Department's stop-and-frisk practices. New York: New York State Office of the Attorney General.

Smith, L. T. (1999). Decolonizing methodologies: Research and indigenous peoples. London: Zed books.

Stein, A. \& Daniels, J. (2017). Going public: A guide for social scientists. Chicago, IL: The University of Chicago Press.

Stoudt, B. G. (2007). The co-construction of knowledge in 'safe spaces': Reflecting on politics \& power in participatory action research. Children, Youth \& Environments, 17(2), 280-297.

Stoudt, B. (2012). "This is exactly what this study is all about and it is happening right in front of me!" Using participatory action research to awaken a sense of injustice within a privileged institution. Journal of Masculinities and Social Change, 1(2), 134-164.

Stoudt, B. (2014). Critical statistics. In T. Teo (Ed.), Encyclopedia of critical psychology (pp. 18501858). New York, NY: Springer Press.

Stoudt, B. G. (2016). Conversations on the margins: Using data entry to explore the qualitative potential of survey marginalia. Qualitative Psychology, 3(2), 186-208. dx.doi.org/10.1037/qup0000060

Stoudt, B. G., Cahill, C., X, D., Belmonte, K., Djokovic, S., Lopez, J., Matles, A., ... Torre, M. E. (2016). Participatory action research as youth activism. In J. Conner \& S. M. Rosen, (Eds.), Contemporary youth activism: Advancing social justice in the United States. New York, NY: ABC-CLIO.

Stoudt, B. G., Fine, M., \& Fox, M. (2011). Growing up policed in the age of aggressive policing policies. The New York Law School Law Review, 56, 1331.

Stoudt, B., Fox, M., \& Fine, M. (2011). Awakening injustice in a new century. In P. Coleman \& J. De Wolfe (Eds.), Conflict, interdependence and justice: The intellectual legacy of Morton Deutsch (pp. 165-191). New York, NY: Springer Press.

Stoudt, B. G., \& Torre, M. E. (2014). The Morris Justice Project. In P. Brindle (Ed.) SAGE cases in methodology. Thousand Oakes, CA: SAGE Publications. 
Stoudt, B. G., Torre, M. E., Bartley, P., Bracy, F., Caldwell, H., Downs, A., Yates, J. (2015). Participatory action research and policy change. In C. Durose \& L. Richardson (Eds.), Designing public policy for co-production: Theory, practice and change (pp. 125-137). Bristol, UK: Policy Press.

Torre, M. E. (2009). Participatory action research and critical race theory: Fueling spaces for nos-otras to research. The Urban Review, 41(1), 106-120.

Torre, M., Fine, M., Stoudt, B., \& Fox, M. (2012). Critical participatory action research as public science. In P. Camic \& H. Cooper (Eds.). The handbook of qualitative research in psychology: Expanding perspectives in methodology and design ( $2^{\text {nd }}$ ed.). Washington, DC: American Psychological Association.

Torre, M. E., \& Ayala, J. (2009). Envisioning Participatory Action Research Entremundos. Feminism and Psychology, 19(3), 387-393.

Torre, M. E., \& Fine, M., with Alexander, N., Billups, A., Blanding, Y., Genao, E., Marboe, M. \& Salah, T. (2008). Participatory action research in the contact zone. In J. Cammarota \& M. Fine (Eds.). Revolutionizing education: Youth participatory action research in motion (pp. 2343). New York: Routledge.

Vitale, A. S. (2008). City of disorder: How the quality of life campaign transformed New York politics. New York: NYU Press.

Wacquant, L. (2009). Punishing the poor: The neoliberal government of social insecurity. Durham, NC: Duke University Press.

Walker, P. (2003). Colonising research: Academia's structural violence towards Indigenous peoples. Social Alternatives, 22(3), 37-40.

Websdale, N. (2001). Policing the poor: From slave plantation to public housing. Chicago, IL: Northeastern University Press. 


\section{About the Authors}

Brett G. Stoudt, John Jay College of Criminal Justice, CUNY

brett.stoudt@gmail.com

Brett G. Stoudt lives with his family in Brooklyn and is an Associate Professor in the Psychology

Department with a joint appointment in the Gender Studies Program at John Jay College of

Criminal Justice as well as the Psychology and Social Welfare Doctoral Programs at the

Graduate Center.

María Elena Torre, Graduate Center, CUNY

mtorre@gmail.com

María Elena Torre lives in Brooklyn with her son and partner and is the founding Director of The

Public Science Project and on the faculty in Critical Social/Personality Psychology and Urban

Education at The Graduate Center of the City University of New York.

Paul Bartley, Graduate Center, CUNY

paulbartley04@gmail.com

Paul Bartley has lived, worked, and raised his 3 children in the Bronx and is the Senior Case

Manager and Certified Recovery Coach Trainer of Trainers at the Acacia Network. He has worked with the mentally ill, homeless and substance abuse populations for nearly 17 years.

Evan Bissell, University of California, Berkeley

evanbissell@gmail.com

Evan Bissell lives in Berkeley, California and is an artist and researcher who organizes narratives for equitable systems and liberatory processes.

Fawn Bracy, Graduate Center, CUNY

fawnbracynyc@gmail.com

Fawn Bracy is a mother and proud recent grandmother who raised her two daughters, son, and nephew in the South Bronx, where she has lived and built community for over 40 years. She has worked with the New York Civil Liberties Union to reform the NYPD and bring policing with dignity and respect to the South Bronx.

Hillary Caldwell, Graduate Center, CUNY

hillcaldwell@gmail.com

Hillary Caldwell lives in Harlem and is a PhD Candidate in Environmental Psychology and the Women's Studies Certificate Program at the Graduate Center of the City University of New York (CUNY). Hillary is also the Assistant Director and Lead Instructor for The Minor in Community Change Studies at City College of New York, CUNY.

Lauren Dewey, University of Vermont lmdewey@gmail.com

Lauren Dewey lives with her family in Vermont and is a clinical supervisor and faculty member in the Department of Psychological Science at the University of Vermont.

Anthony Downs, Graduate Center, CUNY

anthonydowns326@gmail.com 
Anthony Downs is a Bronx native of 34 years who has participated in numerous professional conferences to speak out about police reform and feels a renewed energy to help end aggressive policing practices in NYC.

Cory Greene, Graduate Center, CUNY

coryholla@gmail.com

Cory Greene was born and raised in the inner city of New York and currently a doctoral student in the Critical Social/Personality Psychology program at The Graduate Center of the City University of New York. He is one of the co-founders and co-director of H.O.L.L.A! (How Our Lives Link Altogether).

Jan Haldipur, California State University, Long Branch jhaldi@gmail.com

Jan Haldipur lives in Los Angeles and is an Assistant Professor in the Department of Sociology at California State University, Long Beach. His new book, No Place on the Corner: The Costs of Aggressive Policing (NYU Press) takes an ethnographic look at the consequences of aggressive policing tactics in New York City.

Scott Lizama, Graduate Center, CUNY

lizamascott@gmail.com

Scott Lizama lives with his family in Brooklyn and is a $\mathrm{PhD}$ student in Environmental at the Graduate Center of the City University of New York.

Prakriti Hassan, Graduate Center, CUNY

prakriti.hassan@gmail.com

Prakriti Hassan has been a Bronx resident for over 12 years and through MJP, discovered her passion for research and her strong interest in police reform. She is currently a student in the M.A. Program in Liberal Studies at the Graduate Center of the City University of New York.

Einat Manoff, Graduate Center, CUNY

einatmanoff@gmail.com

Einat Manoff currently lives with her daughter in Canada. She is a doctoral student in the Environmental Psychology Ph.D. program at the CUNY Graduate Center.

Nadine Sheppard, Graduate Center, CUNY

sheppard40965@gmail.com

Nadine Sheppard is a mother of three sons and has lived in the South Bronx for over 20 years. She is deeply committed to ending aggressive and discriminatory policing in her community and the winner of the Linda Powell Pruitt Women who refuse to Surrender Award.

Jacqueline Yates, Graduate Center, CUNY

jackieyates15@yahoo.com

Jacqueline Yates is a mother of two sons, a wife, and has lived in the South Bronx for more than 30 years. She has been actively involved with the New York Civil Liberties Union to reform the NYPD and end aggressive and discriminatory policing practices. 


\section{About the Guest Editors}

\section{Ronald David Glass}

University of California, Santa Cruz

rglass@ucsc.edu

Ronald David Glass is Professor of Philosophy of Education at the University of California, Santa Cruz, USA, and Director of the Center for Collaborative Research for an Equitable California ( $\underline{\text { CCREC }) . ~ H i s ~ r e c e n t ~ w o r k ~ f o c u s e s ~ o n ~ t h e ~ e t h i c s ~ o f ~ r e s e a r c h, ~ a n d ~ t h e ~ f o u n d a t i o n s ~ o f ~ h i s ~}$ philosophy have investigated ideological (trans)formation, education as a practice of freedom, and the role engaged research and public learning processes in struggles for justice.

\section{Mark R. Warren}

University of Massachusetts Boston Mark.Warren@umb.edu

Mark R. Warren is Professor of Public Policy and Public Affairs at the University of Massachusetts Boston. Mark is the author of several books on community organizing for racial equity and educational justice, including Lift Us Up Don't Push Us Out! Voices from the Front Lines of the Educational Justice Movement. He is a co-founder and co-chair of the Urban Research Based Action Network (URBAN).

Guest Associate Editors: Lindsay Morgia (University of Massachusetts, Boston) and Ben Teresa (Virginia Commonwealth University) 


\title{
SPECIAL ISSUE
COLLABORATIVE RESEARCH FOR JUSTICE education policy analysis archives
}

\author{
Volume 27 Number $56 \quad$ May 20, 2019
}

ISSN 1068-2341

\begin{abstract}
(C)
SOMERIGHISRESERVED Readers are free to copy, display, and distribute this article, as long as the work is attributed to the author(s) and Education Policy Analysis Archives, it is distributed for noncommercial purposes only, and no alteration or transformation is made in the work. More details of this Creative Commons license are available at http://creativecommons.org/licenses/by-nc-sa/3.0/. All other uses must be approved by the author(s) or EPAA. EPAA is published by the Mary Lou Fulton Institute and Graduate School of Education at Arizona State University Articles are indexed in CIRC (Clasificación Integrada de Revistas Científicas, Spain), DIALNET (Spain), Directory of Open Access Journals, EBSCO Education Research Complete, ERIC, Education Full Text (H.W. Wilson), QUALIS A2 (Brazil), SCImago Journal Rank; SCOPUS, SOCOLAR (China).
\end{abstract}

Please send errata notes to Gustavo E. Fischman fischman@asu.edu

Join EPAA's Facebook community at https://www.facebook.com/EPAAAAPE and Twitter feed@epaa_aape. 


\section{education policy analysis archives editorial board}

Lead Editor: Audrey Amrein-Beardsley (Arizona State University)

Editor Consultor: Gustavo E. Fischman (Arizona State University)

Associate Editors: David Carlson, Lauren Harris, Eugene Judson, Mirka Koro-Ljungberg, Scott Marley, Molly Ott, Iveta Silova (Arizona State University)

Cristina Alfaro

San Diego State University

Gary Anderson

New York University

Michael W. Apple

University of Wisconsin, Madison

Jeff Bale

University of Toronto, Canada

Aaron Bevanot SUNY Albany

David C. Berliner

Arizona State University

Henry Braun Boston College

Casey Cobb

University of Connecticut

Arnold Danzig

San Jose State University

Linda Darling-Hammond

Stanford University

Elizabeth H. DeBray

University of Georgia

David E. DeMatthews

University of Texas at Austin

Chad d'Entremont Rennie Center

for Education Research \& Policy

John Diamond

University of Wisconsin, Madison

Matthew Di Carlo

Albert Shanker Institute

Sherman Dorn

Arizona State University

Michael J. Dumas

University of California, Berkeley

Kathy Escamilla

University ofColorado, Boulder

Yariv Feniger Ben-Gurion

University of the Negev

Melissa Lynn Freeman

Adams State College

Rachael Gabriel

University of Connecticut
Amy Garrett Dikkers University

of North Carolina, Wilmington

Gene V Glass

Arizona State University

Ronald Glass University of

California, Santa Cruz

Jacob P. K. Gross

University of Louisville

Eric M. Haas WestEd

Julian Vasquez Heilig California

State University, Sacramento

Kimberly Kappler Hewitt University of North Carolina Greensboro

Aimee Howley Ohio University

Steve Klees University of Maryland

Jaekyung Lee SUNY Buffalo

Jessica Nina Lester

Indiana University

Amanda E. Lewis University of

Illinois, Chicago

Chad R. Lochmiller Indiana

University

Christopher Lubienski Indiana

University

Sarah Lubienski Indiana University

William J. Mathis

University of Colorado, Boulder

Michele S. Moses

University of Colorado, Boulder

Julianne Moss

Deakin University, Australia

Sharon Nichols

University of Texas, San Antonio

Eric Parsons

University of Missouri-Columbia

Amanda U. Potterton

University of Kentucky

Susan L. Robertson

Bristol University
Gloria M. Rodriguez

University of California, Davis

R. Anthony Rolle

University of Houston

A. G. Rud

Washington State University

Patricia Sánchez University of

University of Texas, San Antonio

Janelle Scott University of

California, Berkeley

Jack Schneider University of

Massachusetts Lowell

Noah Sobe Loyola University

Nelly P. Stromquist

University of Maryland

Benjamin Superfine

University of Illinois, Chicago

Adai Tefera

Virginia Commonwealth University

A. Chris Torres

Michigan State University

Tina Trujillo

University of California, Berkeley

Federico R. Waitoller

University of Illinois, Chicago

Larisa Warhol

University of Connecticut

John Weathers University of

Colorado, Colorado Springs

Kevin Welner

University of Colorado, Boulder

Terrence G. Wiley

Center for Applied Linguistics

John Willinsky Stanford University

Jennifer R. Wolgemuth

University of South Florida

Kyo Yamashiro

Claremont Graduate University

Miri Yemini

Tel Aviv University, Israel 


\section{archivos analíticos de políticas educativas consejo editorial}

Editor Consultor: Gustavo E. Fischman (Arizona State University)

Editores Asociados: Armando Alcántara Santuario (Universidad Nacional Autónoma de México), Angelica Buendia, (Metropolitan Autonomous University), Alejandra Falabella (Universidad Alberto Hurtado, Chile), Antonio Luzon, (Universidad de Granada), José Luis Ramírez, (Universidad de Sonora), Paula Razquin (Universidad de San Andrés), Maria Alejandra Tejada-Gómez (Pontificia Universidad Javeriana, Colombia)

Claudio Almonacid

Universidad Metropolitana de

Ciencias de la Educación, Chile

Miguel Ángel Arias Ortega

Universidad Autónoma de la

Ciudad de México

Xavier Besalú Costa

Universitat de Girona, España

Xavier Bonal Sarro Universidad Autónoma de Barcelona, España

Antonio Bolívar Boitia

Universidad de Granada, España

José Joaquín Brunner Universidad Diego Portales, Chile

Damián Canales Sánchez Instituto Nacional para la Evaluación de la Educación, México

Gabriela de la Cruz Flores

Universidad Nacional Autónoma de México

Marco Antonio Delgado Fuentes Universidad Iberoamericana, México

Inés Dussel, DIE-CINVESTAV, México

Pedro Flores Crespo Universidad Iberoamericana, México
Ana María García de Fanelli

Centro de Estudios de Estado y Sociedad (CEDES) CONICET, Argentina

Juan Carlos González Faraco

Universidad de Huelva, España

María Clemente Linuesa

Universidad de Salamanca, España

Jaume Martínez Bonafé

Universitat de València, España

Alejandro Márquez Jiménez

Instituto de Investigaciones sobre la Universidad y la Educación, UNAM, México

María Guadalupe Olivier Tellez, Universidad Pedagógica Nacional, México

Miguel Pereyra Universidad de Granada, España

Mónica Pini Universidad Nacional de San Martín, Argentina

Omar Orlando Pulido Chaves Instituto para la Investigación Educativa y el Desarrollo Pedagógico (IDEP) José Ignacio Rivas Flores Universidad de Málaga, España

\author{
Miriam Rodríguez Vargas \\ Universidad Autónoma de \\ Tamaulipas, México \\ José Gregorio Rodríguez \\ Universidad Nacional de Colombia, \\ Colombia \\ Mario Rueda Beltrán Instituto de \\ Investigaciones sobre la Universidad \\ y la Educación, UNAM, México \\ José Luis San Fabián Maroto \\ Universidad de Oviedo, \\ España
}

Jurjo Torres Santomé, Universidad de la Coruña, España

Yengny Marisol Silva Laya

Universidad Iberoamericana,

México

Ernesto Treviño Ronzón

Universidad Veracruzana, México

Ernesto Treviño Villarreal

Universidad Diego Portales

Santiago, Chile

Antoni Verger Planells

Universidad Autónoma de

Barcelona, España

Catalina Wainerman

Universidad de San Andrés, Argentina

Juan Carlos Yáñez Velazco

Universidad de Colima, México 


\section{arquivos analíticos de políticas educativas conselho editorial}

Editor Consultor: Gustavo E. Fischman (Arizona State University)

Editoras Associadas: Kaizo Iwakami Beltrao, (Brazilian School of Public and Private Management - EBAPE/FGV, Brazil), Geovana Mendonça Lunardi Mendes (Universidade do Estado de Santa Catarina), Gilberto José Miranda, (Universidade Federal de Uberlândia, Brazil), Marcia Pletsch, Sandra Regina Sales (Universidade Federal Rural do Rio de Janeiro)

\author{
Almerindo Afonso \\ Universidade do Minho \\ Portugal \\ Rosanna Maria Barros Sá \\ Universidade do Algarve \\ Portugal \\ Maria Helena Bonilla \\ Universidade Federal da Bahia \\ Brasil \\ Rosa Maria Bueno Fischer \\ Universidade Federal do Rio Grande \\ do Sul, Brasil \\ Alice Casimiro Lopes \\ Universidade do Estado do Rio de \\ Janeiro, Brasil

\section{Suzana Feldens Schwertner \\ Centro Universitário Univates \\ Brasil \\ Flávia Miller Naethe Motta \\ Universidade Federal Rural do Rio de Janeiro, Brasil}

\section{Alexandre Fernandez Vaz \\ Universidade Federal de Santa \\ Catarina, Brasil \\ Regina Célia Linhares Hostins \\ Universidade do Vale do Itajaí, Brasil}

\section{Alfredo Macedo Gomes \\ Universidade Federal de Pernambuco}

Brasil

\section{Jefferson Mainardes}

Universidade Estadual de Ponta

Grossa, Brasil

\section{Jader Janer Moreira Lopes \\ Universidade Federal Fluminense e \\ Universidade Federal de Juiz de Fora, Brasil \\ Debora Nunes \\ Universidade Federal do Rio Grande do Norte, Brasil}

\section{Alda Junqueira Marin \\ Pontifícia Universidade Católica de São Paulo, Brasil}

\section{Dalila Andrade Oliveira}

Universidade Federal de Minas

Gerais, Brasil
José Augusto Pacheco

Universidade do Minho, Portugal

Jane Paiva

Universidade do Estado do Rio de

Janeiro, Brasil

Paulo Alberto Santos Vieira

Universidade do Estado de Mato

Grosso, Brasil

Fabiany de Cássia Tavares Silva

Universidade Federal do Mato

Grosso do Sul, Brasil

António Teodoro

Universidade Lusófona

Portugal

Lílian do Valle

Universidade do Estado do Rio de

Janeiro, Brasil

\section{Alfredo Veiga-Neto}

Universidade Federal do Rio Grande do Sul, Brasil 